\title{
Bare singulars and singularity in Turkish
}

\author{
Yağmur Sağ ${ }^{1}$
}

Accepted: 30 January 2021 /Published online: 16 September 2021

(C) The Author(s) 2021

\begin{abstract}
This paper explores the semantics of bare singulars in Turkish, which are unmarked for number in form, as in English, but can behave like both singular and plural terms, unlike in English. While they behave like singular terms as case-marked arguments, they are interpreted number neutrally in non-case-marked argument positions, the existential copular construction, and the predicate position. Previous accounts (Bliss, in Calgary Papers in Linguistics 25:1-65, 2004; Bale et al. in Semantics and Linguistic Theory (SALT) 20:1-15, 2010; Görgülü, in: Semantics of nouns and the specification of number in Turkish, Ph.d. thesis, Simon Fraser University, 2012) propose that Turkish bare singulars denote number neutral sets and that morphologically plural marked nouns denote sets of pluralities only. This approach leads to a symmetric correlation of morphological and semantic (un)markedness. However, in this paper, I defend a strict singular view for bare singulars and show that Turkish actually patterns with English where this correlation is exhibited asymmetrically. I claim that bare singulars in Turkish denote atomic properties and that bare plurals have a number neutral semantics as standardly assumed for English. I argue that the apparent number neutrality of bare singulars in the three cases arises via singular kind reference, which I show to extend to the phenomenon called pseudo-incorporation and a construction that I call kind specification. I argue that pseudo-incorporation occurs in non-case-marked argument positions following Öztürk (Case, referentiality, and phrase structure, Amsterdam, Benjamins, Publishing Company, 2005) and the existential copular construction, whereas kind specification is realized in the predicate position. The different behaviors of bare singulars in Turkish and English stem from the fact that singular kind reference is used more extensively in Turkish than in English. Furthermore, while there are well-known asymmetries between singular and plural kind reference cross-linguistically, Turkish manifests a more restricted distribution for bare plurals than English in the positions where pseudo-incorporation and kind specification are in evidence. I explain this as a blocking effect, specific to Turkish, by singular kind terms on plural kind terms.
\end{abstract}

Yağmur Sağ

yagmur_sag-parvardeh@fas.harvard.edu; yagmursag@gmail.com

1 Harvard University, Boylston Hall, 3rd floor, Cambridge, MA 02138, USA 
Keywords Bare singulars $\cdot$ Bare plurals $\cdot$ Number interpretation $\cdot$ Kind reference $\cdot$ Pseudo-incorporation

\section{Introduction}

Turkish nouns, like English nouns, come in two forms. One is unmarked for number (Turkish kitap; English book) and one is morphologically marked plural (Turkish kitap +lar; English book $+s$ ). While unmarked nouns in English are readily identified as singular terms since they consistently give rise to singular interpretations, the picture is less clear for Turkish unmarked nouns, which sometimes seem to behave like singular terms and sometimes like plural terms. Yielding a strictly singular interpretation as case-marked arguments, e.g., Ali kitab- $\iota$ okudu. 'Ali read the book.', they can refer to more than one entity in three specific cases: (i) as non-case-marked direct objects, e.g., Ali kitap okudu. 'Ali read one or more books.' (ii) in existential statements, e.g., Odada fare var. 'There are one or more mice in the room.', and (iii) in the predicate position, e.g., Ali ve Merve çocuk. 'Ali and Merve are children.'

There are two approaches one can take in addressing this challenge. One can take them to be fundamentally number neutral/plural terms or one can take them to be fundamentally singular terms. Regardless of which approach is adopted, the challenge is to account for those cases where the base assumption does not work. On the view that unmarked nouns are essentially number neutral terms, one needs a principled account for instances when that neutrality is not in evidence; on the view that unmarked nouns are essentially singular terms, one needs a principled account for instances where the singularity is not in evidence. ${ }^{1}$

The three cases where number neutrality is evidenced have led Bliss (2004), Bale et al. (2010), and Görgülü (2012) to pursue the first approach and claim that Turkish unmarked nouns include atomic and plural entities in their denotation while the plural marked nouns denote pluralities only. While this approach classifies Turkish as a language which draws a parallel between morphological and semantic (un)markedness, this match is not attested in many other languages, including English, where the semantic reflection of morphological (un)markedness is realized in the opposite way. The standard assumption for English is that unmarked nouns denote atomic entities only whereas plurals are unspecified for number (Krifka 2003; Sauerland et al. 2005; Spector 2007; Zweig 2009).

This paper shows that Turkish actually patterns with English in the semantics of number marking. More precisely, I claim that Turkish unmarked nouns denote atomic properties, while plurals are inclusive of atoms and their pluralities. I argue that the seemingly number neutral reading of bare singulars in the three cases arises via singular kind reference.

Following Chierchia's (1998) analysis of plural kind reference and Dayal's (2004) analysis of singular kind reference, I argue that in Turkish, as in English, singular kind terms differ from plural kind terms in being grammatically (impure) atomic, though

\footnotetext{
1 Treating unmarked nouns as ambiguous between singular and plural terms may reduce to the first approach.
} 
they remain true to the notion of kind, retaining a relation with the atomic and plural specimens at the conceptual level. I further argue that Turkish in fact resorts to this relation in the grammatical component, establishing it as part of the phenomenon called pseudo-incorporation in non-case-marked argument positions and existential statements (cf. Öztürk 2005; Dayal 2011, 2015), and as part of a phenomenon that I call kind specification in the predicate position. The establishment of this relation ensures a number neutral reading in these constructions and this extensive use of singular kind reference is what separates Turkish from English in terms of their unmarked nouns. We will see that English also resorts to singular kind reference in a similar way with so-called weak definites, though only to a limited extent (Aguilar-Guevara and Zwarts 2010). I unify this phenomenon with Turkish pseudo-incorporation, but the productive status of the latter makes the number neutrality associated with these phenomena easier to detect in Turkish than in English, resulting in the illusion that Turkish unmarked nouns must be number neutral.

We will also see that Turkish adds a new dimension to the cross-linguistic picture of pseudo-incorporation and kind reference. Singular kind terms seem to block plural kind terms in the non-case-marked direct object and predicate positions, revealing an interesting asymmetry between the two forms of kind reference. The privileged status of singular kind terms results in a more restricted use for plural nouns in Turkish compared to English.

Before we begin, a note on terminology is in order. The term bare refers to determinerless noun phrases, following the convention in Carlson (1977) and neo-Carlsonian studies on English bare plurals. Thus, I refer to nouns that are unmarked for number as bare singulars, whereas I refer to nouns inflected with -lAr as bare plurals. That is, as long as they are not accompanied by an overt determiner, nouns will be regarded as bare even if they have case-marking on them.

This paper is organized as follows: Sect. 2 introduces the core data and details the number-based puzzles to be solved. Section 3 discusses earlier analyses of Turkish bare singulars and plurals and presents the stance taken here with respect to their semantics. This section also introduces pseudo-incorporation in light of the analysis proposed in Dayal (2011, 2015). Section 4 examines the nature of kind reference in Turkish in comparison with kind reference in English. Section 5 explains the number neutrality of bare singulars in the three cases noted above. Section 6 discusses remaining issues and predictions, focusing on the comparison of pseudo-incorporation with case-marked arguments and the blocking effect of singular kind terms on plural kind terms. Section 7 concludes.

\section{Number-based puzzles in Turkish}

Turkish posits an interesting puzzle to the cross-linguistic picture of nominal semantics. As has been observed by various scholars, Turkish bare singulars yield a number neutral interpretation in certain cases, whereas they give rise to a strictly singular interpretation in other cases.

The number neutral interpretation of bare singulars arises in the non-case-marked direct object position, as in (1a), the position immediately preceding the existential 
copula var, as in (1b), and the predicate position, as in (1c), where a bare singular is predicated of a plural subject. I will refer to the construction in (1b) as the existential copular construction from now on.
a. Ali kitap oku-du.
Ali book read-PAST
'Ali read one or more books.'
b. Oda-da fare var.
room-LOC mouse exist
'There are one or more mice in the room.'
c. Ali ve Merve çocuk.
Ali and Merve child
'Ali and Merve are children.'

The strict singular interpretation of bare singulars is observed in case-marked argument positions, i.e., case-marked subject, direct object, and indirect object positions, where they are also interpreted as definite: ${ }^{2}$
a. Çocuk ev-e koş-tu.
child home-DAT run-PAST
'The child ran home.' (undefined if more than one child ran home)
b. Ali kitab-1 oku-du.
Ali book-ACC read-PAST
'Ali read the book.' (undefined if Ali read more than one book)
c. Ali çocuğ-a kitab-1 ver-di.
Ali child-DAT book-ACC give-PAST
'Ali gave the book to the child.' (undefined if Ali gave it to more than one child)

This dual nature of bare singulars makes it hard to immediately identify them as singular or plural/number neutral terms. In case-marked argument positions they behave like singular terms, as in English, whereas unlike in English, there are the three cases where they behave like number neutral terms.

A challenge that I introduce into this picture comes from the contrast observed when bare singulars are modified. Only certain types of adjectives are compatible with the number neutral reading of bare singulars in the constructions given in (1). Crucially, we do not observe a similar effect in case-marked argument positions.

Let us start with bare singulars that occur in the non-case-marked direct object position. They are restricted in terms of modification, as exemplified in the following contrast: The modification of book with religious or scientific is possible, as in (3a), where the bare singular book yields 'one or more books' interpretation. In contrast, the modification of book with old, meaning worn-out as opposed to ancient/historical,

\footnotetext{
2 As the bare singulars in (2) are interpreted as both singular and definite, the sentences are not plainly false but undefined in the given contexts. Turkish lacks an overt definite article and both bare singulars and plurals can occupy argument positions. The general consensus about subjects is that they have a null nominative case marker. However, in Sect. 5.1.3, we will see that subjects can also be caseless under certain conditions, and that caseless bare singular subjects yield a number neutral reading, as in (1a). See also Johanson (1977), Kornfilt (1984, 1997, 2009), and von Heusinger and Kornfilt (2005).
} 
or the adjective small yields ungrammaticality, as in (3b), which instead requires the indefinite or plural forms.

a. Ali, ev-e geldikten sonra, dini/ bilimsel kitap oku-du.

Ali home-DAT having.come after religious scientific book read-PAST

'After he came home, Ali read one or more religious/scientific books.'

b. *Ali, ev-e geldikten sonra, eskil küçük kitap oku-du.

Ali home-DAT having.come after old small book read-PAST

'After he came home, Ali read one or more old/small books.'

What seems to be common to the adjectives that are acceptable is that they establish a sub-type of the noun that they modify; they denote classificatory properties in a sense. While religious/scientific books can be considered sub-types of books, it is harder to establish this relation with worn-out/small books. The second set of adjectives simply define physical properties of the book/books that were read. ${ }^{3}$

The same restriction in modification is also observed with bare singulars in the existential copular construction, except that non-sub-type forming adjectives are also possible in this construction. However, this possibility introduces a contrast in terms of number interpretation. If the adjective yields a sub-type of the noun that it modifies, as in (4a), then the bare singular either yields a singular definite or a number neutral non-specific reading. With adjectives like old/small, on the other hand, the number neutral non-specific reading disappears, as in (4b). ${ }^{4}$

\section{a. Kutu-da dinil bilimsel kitap var.}

box-LOC religious scientific book exist

'This box has the religious/scientific book.'

'There are one or more religious/scientific books in this box.'

b. Kutu-da eski/ küçük kitap var.

box-LOC old small book exist

'This box has the old/small book.' (undefined if more than one old/small book)

Setting aside the alternation between definiteness and non-specificity at this point, this contrast highlights, once again, the correlation between number neutrality and the classificatory nature of the modifier.

Let us now see how these facts play a role in the predicate position: In Turkish, both bare singulars and indefinites can appear in the predicate position with a singular

\footnotetext{
3 Some other adjectives that cannot modify book in (3b) are güzel 'nice', kısa 'short', and sıkıcl 'boring'. Another example is Ali dün nostaljik/*sıkıcı film izledi. 'Ali watched one or more nostalgic/*boring movies.' While nostalgic movies are a type of movies, boring movies are not easily taken to be so. Notice though that what counts as sub-types depends on the verb and the context, as we will discuss further in Sect. 5.1.1.

${ }^{4}$ I assume that old is not interpreted as ancient/historical. Note, though, in a context where old is considered as a classificatory property, for example, when books are boxed based on whether they are old or new, then old can gain a sub-type forming function yielding a number neutral reading. This also holds for the adjective small. The point is that the classificatory readings of these adjectives require significant contextual support, but with the modifiers in (4a), the sentences yield a number neutral reading even in out-of-the-blue contexts.
} 
subject. If the subject is plural, indefinites are ruled out as expected. Bare singulars, however, remain possible: ${ }^{5}$
a. Ali (bir) çocuk.
Ali one child
'Ali is a child.'
b. Ali ve Merve (*bir) çocuk.
Ali and Merve one child
'Ali and Merve are children.'

The picture changes when we add modification to the predicate and, not surprisingly at this point, the nature of the modifier makes a difference. For example, the adjective practitioner defines a type of doctor and when it modifies the bare singular doctor as in (6a) the result is compatible with a singular or a plural subject. The adjective handsome does not have such a function and its combination with doctor as in (6b) is only compatible with a singular subject. ${ }^{6}$

a. Ali (ve Mehmet) pratisyen doktor.

Ali and Mehmet practitioner doctor

'Ali is a practitioner doctor./Ali and Mehmet are practitioner doctors.'

b. Ali (*ve Mehmet) yakışıll doktor.

Ali and Mehmet handsome doctor

'Ali is a handsome doctor.' Not: 'Ali and Mehmet are handsome doctors.'

To wrap up, in all three cases, i.e., the non-case-marked direct object position, the existential copular construction, and the predicate position, the number interpretation of a bare singular varies depending on the modification type. Another puzzle, then, is to understand what kind of a role different types of modification play in the number interpretation of bare singulars in these cases and why they do not have similar effects in case-marked argument positions.

There is one more aspect of Turkish bare singulars that contributes to the puzzles about number interpretation: Singular as well as plural terms can be used for kind reference cross-linguistically but they also have some well-attested differences. We see this in Turkish as well. While both bare singulars and bare plurals can be used in kind-level statements, only bare plurals are compatible with predicates that involve a reciprocal relation between individual members of the species:

a. Dinozor(-lar) 250 milyon yıl önce evrimleş-miş-tir.

dinosaur-PL 250 million year ago evolve-PERF-GEN

'The dinosaur/Dinosaurs evolved 250 million years ago.'

\footnotetext{
5 (5) is considered strange by native speakers, without accompanying adverbial elements like hala/henüz 'still', but we can set this aside as it does not affect the point under discussion.

6 A reviewer questions whether dini kitap 'religious book' and pratisyen doktor 'practitioner doctor' could be compounds. There are some tests to distinguish noun phrases modified by adjectives from compounds. For example, while compounds do not allow the indefinite marker bir to intervene between the first and second elements, e.g., *yün bir çorap 'a woolen sock', an adjective+noun combination does. Dini and pratisyen pattern with the latter, e.g., dini bir kitap 'a religious book', Pratisyen bir doktora ihtiyacımız var. 'We need a practitioner doctor.'
} 
b. Ayı(-lar) genelde saldırgan ol-ur. bear-PL generally aggressive be-AOR 'The bear is/Bears are generally aggressive.'

c. Kedi*(-ler) birbiri-ne saldır-1r. cat-PL each.other-DAT attack-AOR 'Cats attack each other./*The cat attacks each other.'

Considering that kinds are inherently plural entities, bare singulars convey a number neutral interpretation in some sense when they have a kind reference. In (7a), the reference is to the totality of the dinosaur kind, and (7b) expresses a property of bears in general. But clearly, this is not enough to meet the plurality requirement of distributive elements like reciprocals, as the contrast in (7c) demonstrates. To put it differently, bare singulars do not entirely behave like plural terms when they refer to kind entities. Therefore, the kind-level characteristics of bare singulars also need to be taken into consideration in explaining their dual nature in terms of number interpretation.

Now that we have some understanding of the puzzles that number marking and number interpretation present in Turkish, we can turn to the theoretical background against which they can be analyzed. We can consider the core meaning of bare singulars to be defined by either their singular behavior or their number neutral behavior, but in either approach we need to provide a principled explanation for those cases in which bare singulars convey an interpretation against the core assumption.

\section{Theoretical backdrop}

In this section, I first discuss and argue against the previous accounts of Turkish nominal semantics, where bare singulars are treated as number neutral terms and bare plurals as having a strictly plural denotation. I then propose an alternative view where it is bare plurals that are in fact number neutral in Turkish, while bare singulars are strictly singular terms, similar to the views adopted for English nominals. That is, I take the core semantics of number marking in Turkish and English to be the same. Finally, I discuss pseudo-incorporation since among the three constructions where bare singulars yield number neutrality, the non-case-marked direct object position has received some attention under this phenomenon. Presenting a widely-known account of pseudo-incorporation, I show that the facts of Turkish call for a separate analysis.

\subsection{Number neutral bare singulars, strictly plural bare plurals}

Since the seminal work of Link (1983), the mereological treatment of pluralities has become a well-established tradition in the semantic literature, where the domain of individuals $\left(D_{e}\right)$ has been assumed to include atoms and their closure under sum formation $\oplus$, by the 'star' operator *. That is, * applying to a $\mathrm{P}$ returns the closure of $\mathrm{P}$ under $\oplus$, therefore ${ }^{*} \mathrm{P}$ is a set inclusive of atoms and their sums. $\llbracket^{*} P \rrbracket$ is itself a complete atomic join semilattice, as shown below. So, in a model where the books are $\mathrm{a}, \mathrm{b}$, and c, book denotes an atomic set with the members a, b, c and books denotes a 
number neutral set inclusive of atoms $\mathrm{a}, \mathrm{b}, \mathrm{c}$, and their pluralities $\mathrm{a} \oplus \mathrm{b}, \mathrm{a} \oplus \mathrm{c}, \mathrm{b} \oplus \mathrm{c}$, and $\mathrm{a} \oplus \mathrm{b} \oplus \mathrm{c}$. (Throughout the paper, I assume this model for ease of exposition.)

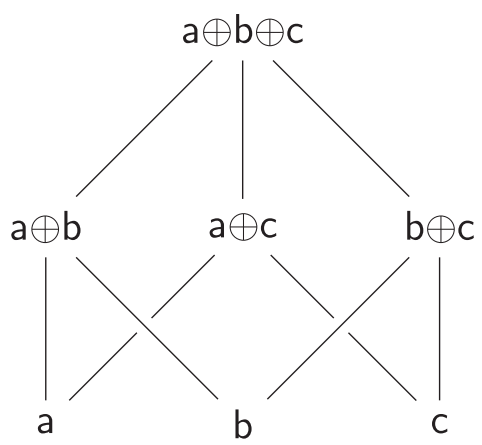

The semantics of Turkish bare nouns has received attention in the works of Bliss (2004), Bale et al. (2010), and Görgülü (2012), where it has been argued that bare singulars like kitap 'book' denote number neutral sets in Turkish, as given in (8). This account is based on the number neutral interpretation of bare singulars in the three positions, the non-case-marked direct object position (Bliss 2004; Görgülü 2012), the existential copular construction (Görgülü 2012), and the predicate position (Bale et al. 2010; Görgülü 2012), shown in (1) above.

$$
\llbracket k i t a p \rrbracket=\{a, b, c, a \oplus b, a \oplus c, b \oplus c, a \oplus b \oplus c\}
$$

Bliss (2004), Bale et al. (2010), and Görgülü (2012) further argue that Turkish bare plurals are strictly plural; they denote pluralities only, exclusive of atoms, as represented in $(9){ }^{7}$

$$
\llbracket k i t a p+P L \rrbracket=\{a \oplus b, a \oplus c, b \oplus c, a \oplus b \oplus c\}
$$

This analysis treats Turkish, along with Western Armenian, for example, as one of the few languages where the morphologically marked plurals are also semantically marked in having a strictly plural denotation, while the morphologically unmarked singulars are also unmarked in having a number neutral denotation (see Bale et al. 2010; Bale and Khanjian 2014 for Western Armenian). On the other hand, many other languages, English being one of them, exhibit an asymmetric relation between morphological and semantic (un)markedness. While singulars are semantically marked as having a strict singular denotation, plurals are argued to have an unmarked denotation in these languages (see Krifka 2003; Sauerland et al. 2005; Spector 2007, and Zweig 2009 for English).

As pointed out above, though, the challenge for treating bare singulars as number neutral is to account for those cases where they receive a singular reading. Although

\footnotetext{
7 The evidence that Bale et al. (2010) use for their strict plural account of Turkish bare plurals is the fact that they can be predicated of plural subjects, but not singular subjects. The details of the behavior of bare plurals in the predicate position will be discussed in Sect. 6.2. See also fn. (53).
} 
this issue has not been addressed by Bale et al. (2010) and Görgülü (2012), Bliss (2004) offers a syntactic explanation. She argues that case-marked nouns are DPs since they are always interpreted as definite. DPs have a Number Phrase (NumP) in them, which is headed by a null Number head that bears a default singular feature, when it is not filled by the plural marker. This results in the singular interpretation of case-marked bare singulars. Non-case-marked bare singulars, though, are NPs and hence they are unspecified for number. While a solution like this explains the singularity of bare singulars that are also definite in case-marked argument positions and the existential copular construction, it does not predict the fact that the number interpretation is sensitive to the type of adjectival modification. Specifically, in the predicate position, a bare singular modified by a non-sub-type forming adjective, as in (6b), behaves as a singular term, yet it is not (necessarily) interpreted as definite. That is, it is not clear why handsome doctor in (6b) would include a NumP projection, while practitioner doctor in (6a) would merely be an NP. ${ }^{8}$

A further challenge for the view adopted in these works comes from bare plurals. In fact, they are not strictly plural in Turkish, but rather they are number neutral terms, as Sect. 3.2 shows.

\subsection{Number neutral bare plurals, strictly singular bare singulars}

In this section, I discuss and argue for an alternative view where it is in fact bare plurals that are number neutral terms while bare singulars are strictly singular in Turkish.

Turkish bare plurals, I claim, are inclusive of both atoms and their pluralities. That is, instead of (9), the denotation of a bare plural is as shown in (10). This is based on the arguments presented in the implicature-based accounts of English bare plurals.

$$
\llbracket k i t a p+P L \rrbracket=\{a, b, c, a \oplus b, a \oplus c, b \oplus c, a \oplus b \oplus c\}
$$

As is well known for English bare plurals, Turkish bare plurals are associated with more than one possible interpretation. Although they contain multiplicity as part of their interpretation in positive contexts, as exemplified in (11a), they lose that requirement in downward entailing contexts, as in (11b), and in questions, as in (12a), conveying instead an inclusive/number neutral reading (see also Kan 2010). ${ }^{9}$ In other words, the 'more than one' reading, the so-called exclusive reading, does not seem to be strictly part of their interpretation.

a. Çocuk-lar sokak-ta top oynu-yor.

child-PL street-LOC ball play-PROG

\footnotetext{
8 One other solution would be to derive the singularity as a conversational implicature through a competition with the plural form, based on scalar reasoning (Grice 1975). However, this approach does not explain the modification puzzle, either. It also wrongly predicts a singular reading for bare singulars in the existential copular construction. Note though that its predictions cannot be tested in the non-case-marked direct object position since plurals and singulars are not available in this position interchangeably. We discuss this in Sect. 6.2.

9 The examples in (11) and (12a) are ambiguous in having a non-specific and a definite reading. Here, we are concerned with the former. The definite reading of bare plurals will be discussed in Sect. 4.1.
} 
'Children are playing ball on the street.'

$\rightsquigarrow$ More than one child is playing ball on the street.

EXCLUSIVE

b. Çocuk-lar sokak-ta top oyna-mı-yor.

child-PL street-LOC ball play-NEG-PROG

'Children aren't playing ball on the street.'

$\leftrightarrow \rightarrow$ It is not the case that more than one child is playing ball on the street.

$\rightsquigarrow$ No children are playing ball on the street. INCLUSIVE

a. Orman-da ayı-lar-la karşılaş-tı-nız mi?

forest-LOC bear-PL-COM come.across-PAST-2PL QUEST

'Did you come across bears in the forest?

b. Evet, bir tane gör-dü-k./ \#Hayır, bir tane gör-dü-k. yes, one CL see-PAST-1PL no, one CL see-PAST-1PL 'Yes, we saw one./ \#No, we saw one.'

While for (11a) to be true, more than one child needs to be playing ball on the street, (11b) doesn't merely convey that more than one child isn't playing; rather it conveys that no children at all are playing. Similarly, the question in (12a) is not about seeing more than one bear, since seeing one bear is sufficient for an affirmative answer.

Krifka (2003), Sauerland et al. (2005), Spector (2007), and Zweig (2009) argue that bare plurals in English denote atoms as well as pluralities (cf. Farkas and de Swart 2010; Martí 2020a; Grimm 2013). Following this approach for Turkish bare plurals, we make the correct predictions for (11b) and (12a). However, what needs to be explained is how the exclusive reading is derived in cases like (11a). ${ }^{10}$ Spector (2007) and Zweig (2009) argue that the exclusive reading arises as a result of a conversational implicature in positive contexts, for which they adopt a scalar implicature account. ${ }^{11}$

I will now illustrate how the exclusive reading in (11a) is derived as an implicature via scalar reasoning, under the number neutral approach for plurals. Consider a scenario where exactly one child is playing ball on the street. This situation could be described as in (13), conveying the singularity directly, which is true iff exactly one child is playing. The core meaning of (11a), which I represent as $C$ in (14), is an inclusive interpretation. $C$ competes with the alternative statement in (13), in this scenario. $^{12}$

(13) Tam olarak bir (tane) çocuk sokak-ta top oynu-yor.

exactly one CL child street-LOC ball play-PROG

'Exactly one child is playing ball on the street.'

\footnotetext{
10 The strict plural approach directly captures the exclusive reading in (11a), but this account wrongly predicts an exclusive reading for (11b) and (12a) as well. We would expect (11b) to be true in a situation where only one child is playing and we would expect the response to the question in (12a) to be 'no' instead, contrary to the fact.

11 Sauerland et al. (2005) also argue that the exclusive reading is a result of a conversational implicature, but he derives it based on Maximize Presupposition (Heim 1991). Krifka (2003) does not attempt to account for the exclusive reading, but rather focuses on kind-based interpretations of bare plurals.

12 The choice of the alternative sentence competing with the plural form shows variation in the implicature accounts. See Tieu and Romoli (2018) for an overview.
} 
(14) $\quad \mathrm{C}=$ One or more children are playing ball on the street.

INCLUSIVE

The hearer reasons as follows: They assume that the speaker will convey the strongest information that they believe to be true, where a sentence S1 is stronger/more informative than a sentence S2 iff S1 is true in fewer scenarios than S2 (Grice 1975). Since (13) is true in fewer scenarios than (11a), it is stronger. Then, hearing (11a), the hearer assumes that the stronger alternative must be false. The truth of the core meaning of (11a) (i.e., $C$ in (14)) and the hearer's assumption for (13) combine to yield the following scalar meaning for (11a), which I show as $C+$ scalar below. Thus, the plural receives an exclusive interpretation.

(15) $\mathrm{C}+$ scalar $=$ One or more children are playing ball on the street and it is not true that exactly one child is playing ball on the street.

$\mathrm{C}+$ scalar $=$ More than one child is playing ball on the street. EXCLUSIVE

In the negative case, on the other hand, the entailment relations are reversed. Thus, the negation of the alternative statement shown in (16) is weaker than the core meaning of (11b) given in (17). Based on this, the hearer does not make any assumptions regarding (16), and therefore the core meaning of (11b) is maintained. The plural is interpreted number neutrally. ${ }^{13}$

(16) Tam olarak bir (tane) çocuk sokak-ta top oyna-mı-yor.

exactly one CL child street-LOC ball play-NEG-PROG

'It is not the case that exactly one child is playing ball on the street.'

(17) $\mathrm{C}=$ It is not the case that one or more children are playing ball on the street. (No children are playing.)

INCLUSIVE

Confirming its systematicity, the 'one or more' reading of bare plurals is also available in other downward entailing contexts such as the antecedents of conditionals, as in (18a), and the restrictor of universal quantifiers, as in (18b). In both, the bare plural erkekler 'men' is interpreted number neutrally.

a. Eğer erkek-ler tarafından aldat-1l-d1-y-sa-n, sen de if man-PL by cheat-PASS-PAST-COP-COND-2SG you also biz-e katıl-abil-ir-sin. we-DAT join-ABIL-AOR-2SG

'If you have been cheated by men, you can join us.' (one or more men)

b. Erkek-ler tarafından aldat-1l-an herkes biz-e man-PL by cheat-PASS-REL everybody we-DAT katıl-abil-ir. join-ABIL-AOR.

'Everyone who has been cheated by men can join us.' (one or more men)

\footnotetext{
13 The exclusive reading of bare plurals could also be explained based on Maximize Presupposition, which favors the one with the stronger presupposition when two forms compete, on the condition that no presupposition violation occurs (Heim 1991). In that case, the implicature in (11a) would surface due to the stronger presupposition of the alternative sentence and disappear in (11b) due to its weaker status.
} 
In line with the argumentation for English bare plurals, then, I argue that Turkish bare plurals are number neutral and the exclusive reading in positive contexts arises as a result of a conversational implicature (see Renans et al. 2020 for experimental evidence). ${ }^{14}$ However, it is also worth noting that the implicature account does not extend to bare singulars in the cases where they convey a number neutral reading, and so it is of limited value for Turkish.

Let me recap the discussion so far: We have seen that taking bare singulars to denote number neutral sets may provide a simple solution for their number neutrality in certain positions, but is unable to handle their singularity in other positions. Furthermore, we have seen that Turkish bare plurals must in fact be analyzed as number neutral terms, rather than strict plural terms. Recall also that modification has a restrictive role in the cases where bare singulars denote number neutral readings, whereas it does not create a contrast in case-marked argument positions when bare singulars denote strictly singular interpretations only. Delaying the discussion of their status as kind terms until Sect. 4, I thus analyze bare singulars in Turkish as atomic predicates, as illustrated in (19).

$$
\llbracket k i t a p \rrbracket=\{a, b, c\}
$$

This is the first of the core claims that I make regarding the semantics of Turkish bare singulars. Throughout the paper, I will list these claims with Roman numerals, for ease of exposition:

I. In Turkish, bare singulars denote properties of atomic individuals, while bare plurals denote properties of atomic and plural individuals.

This view relocates Turkish among the more commonly attested class of languages like English where the correlation between morphological and semantic (un)markedness is manifested asymmetrically. ${ }^{15}$

Having taken the singular reading of bare singulars as their base denotation, now the challenge is to explain the cases where Turkish differs from English. ${ }^{16}$ That is, it remains to be explained how the number neutral reading arises in the three constructions and how modification plays a role in it. As stated above, non-case-marked

\footnotetext{
14 Görgülü (2012) argues for the strict plural view, providing examples of plurals in the existential copular construction with a possessive meaning where they exhibit an exclusive reading, e.g., Çocuklarınız var $m \imath$ ? 'Do you have children?' However, native speakers find such questions awkward and instead prefer the version with bare singulars, which have a number neutral reading in this construction, as stated above. Additionally, there are some native speakers who still interpret plurals number neutrally in these questions (see also Kan 2010). As is clear in the examples above, once we move away from this construction that results in forced and unreliable judgements, the number neutral reading of bare plurals becomes visible.

15 See Sağ (2019) where the same conclusion is reached for Western Armenian as well.

16 Turkish numerals, unlike in English, are incompatible with plurals, which is surprising on one view of numeral semantics, where they are treated as restrictive modifiers in the sense of Link (1987). Bale et al. (2010) take this disparity between the two languages as an argument for the number neutral view of Turkish bare singulars. However, there is an alternative view where numerals are argued to combine with atomic properties based on Turkish, Hungarian, and Welsh, despite the appearance of the noun in English (Ionin and Matushansky 2006; see also Să 2018, 2019; Martí 2020b, and Scontras 2014). Hence, the counting constructions are amenable to the strict singular view of Turkish bare singulars. Additionally, çok 'many/a lot of' and birkaç 'a few' also combine with singular nouns rather than plurals. I suggest that they can also be considered to presuppose atomicity like numerals.
} 
bare singulars have been argued to undergo pseudo-incorporation in the literature. I therefore present the core aspects of this phenomenon and show that a new analysis is needed to account for Turkish pseudo-incorporation.

\subsection{Pseudo-incorporation}

Öztürk (2005) claims that non-case-marked bare singulars occupying the direct object position in Turkish are instances of pseudo-noun incorporation (PI, henceforth), a term originally due to Massam (2001). The relevant example is repeated here in (20).

Ali kitap oku-du.

Ali book read-PAST

'Ali did book-reading.' (one or more books)

Among the most notable syntactic characteristics of PI-ed nouns is the fact that they form a unit with the verb, while retaining their independent phrasal status at the same time, evidenced by the fact that they can be modified (Taylan 1984; Arslan-Kechriotis 2006; Öztürk 2005). That is, they immediately precede the verb, and they are unable to undergo case-driven movements such as passivization. However, they can be separated from the verb for pragmatic purposes (e.g., contrastive topic or focus) (Öztürk 2009; Sezer 1996; Gračanin-Yüksek and İşsever 2011, among others; see also Dayal 2003, 2011 for Hindi). ${ }^{17}$ On the other hand, canonical arguments like definites, quantified expressions, etc. differ from PI-ed nouns in being free in terms of movement and their ability to be case-marked. In virtue of the syntactic properties that separate non-casemarked bare singulars from canonical arguments, then, I adopt the following claim:

\section{Non-case-marked bare singulars are instances of PI.}

Let us now consider the semantic properties that have been taken to characterize PI. Like canonical incorporation, PI allows for a number neutral interpretation for bare singulars and it is not a fully productive process. As noted by Mithun (1984), it is only available if it conveys an institutionalized/enriched activity or state, which is also known as name-worthiness. That is, incorporation yields an interpretation of a canonically recognized type of activity in a sense. Furthermore, PI-ed bare nouns take obligatory narrow scope when they interact with scope taking elements. ${ }^{18}$ These properties have been the focus of a number of accounts (e.g., Bittner 1994; van Geenhoven 1998; Chung and Ladusaw 2004; Farkas and de Swart 2003; Dayal 2003, 2011, 2015).

\footnotetext{
17 Turkish is a scrambling language, and hence allows movement for pragmatic purposes. Notice also that PI in Turkish contrasts with noun incorporation in languages like Mohawk and Inuit, where the incorporated noun is argued to combine with the verb root, forming a morphologically complex compound verb in Baker (1988, 1996) and Baker et al. (2005) (cf. Mithun 1984), thereby casting a strict ban on the separation of the noun from the verb.

18 Another issue that is widely discussed in PI literature is the (in)ability of incorporated nouns to support discourse anaphora. As is widely known, this is a tricky empirical domain in which the consultants do not provide uniform judgments. So it will not be addressed here, awaiting more systematic judgment elicitations. See Seidel (2020a, b).
} 
Among these, Dayal (2011, 2015), centering on PI in Hindi, comes closest to my position since she claims that singular nouns involved in PI denote atomic properties but can still yield number neutrality.

The technical details of Dayal's account rely on the assumption that verbs have an incorporating version besides their canonical transitive form. The incorporating version takes an atomic property rather than an individual as its internal theme argument, which simply modifies the verb, resulting in a predicate of sub-types of events. Consider mouse-catching, which is a sub-type of catching events (Dayal 2011, p. 147):

$$
\begin{aligned}
& \llbracket \text { mouse-catch } \rrbracket=\lambda y \lambda e . \text { mouse-catch }(e) \wedge \operatorname{Agent}(e)=y, \text { where } \\
& \exists e[\text { mouse-catch }(e)]=1 \text { iff } \exists e^{\prime}\left[\operatorname{catch}\left(e^{\prime}\right) \wedge \exists x\left[\operatorname{mouse}(x) \wedge \operatorname{Theme}\left(e^{\prime}\right)=x\right]\right]
\end{aligned}
$$

In this theory, the narrow scope property of PI is expected since any element taking scope over the verb also takes scope over its nominal modifier. ${ }^{19}$ Number neutrality is dependent on aspectual specification. It is only available when the aspect supports atelic or habitual interpretations. Atelic interpretation entails an iterativity of sub-events and habituality entails a quantificational structure presupposing a plural quantificational domain. Each sub-event in an iterative context or each sub-event forming the atomic part of a plural quantificational domain in a habitual structure has a singular individual as its theme argument. For example, in an iterative context, Anu mouse-caught would mean the following: There exists an event $E$ with sub-events of mouse-catching, each of which has Anu as its agent, and each sub-event of catching has a mouse as its theme.

The evidence for the interaction between number interpretation and aspectual specification comes from the fact that in telic contexts, which are defined on atomic events, the number neutrality disappears and PI yields a singular reading in Hindi. Specifically, when Hindi book-read occurs with an atelic adverbial modifier such as for three hours, the interpretation of the PI-ed noun is 'one or more books'. In contrast, when it occurs with a telic adverbial such as in three hours, the PI-ed noun yields a strictly singular reading, i.e., 'exactly one book'. Dayal takes this to show that neutrality cannot be a property of PI-ed bare singulars in Hindi.

Turning back to Turkish, Dayal's account offers a good starting point for the strict singular view of bare singulars. However, the test that Dayal appeals to in her account of number neutrality reveals a surprising cross-linguistic difference when applied to Turkish. With telic adverbial modification, singularity is the most salient reading, as predicted by Dayal's theory, but it can easily be overridden with good contextual support (see also Kan 2010). Imagine that we want to play football, but we need more people to form two teams. Then, Ali disappears and after half an hour, he returns with 10 people. I explain this situation to someone else as in (22), where the PI-ed bare singular yields a number neutral reading, as evidenced by the follow-up in (22a). This shows that the number neutrality of PI cannot be dependent on aspectual specification in Turkish. ${ }^{20}$

\footnotetext{
19 See Sadock (1980), Bittner (1994), van Geenhoven (1998), and Farkas and de Swart (2003) for other approaches to the obligatory narrow scope interpretation of PI-ed nominals.

20 Dayal supports the claim that PI-ed singular nouns denote atomic properties with a contrast in Hungarian PI created by the verbs collect and gather on the one hand, and verbs like compare and unite on the other
} 
a. Ali yarım saat-te adam bul-muş/ topla-mış.

Ali half hour-LOC man find-EVID/ collect-EVID

'Ali did man-finding/collecting in half an hour.'

b. Bir baktık, on kişiyle geliyor. Halbuki biz onun bir kişi bile bulabileceğinden emin değildik.

'All of sudden, he came with ten people. In fact, we weren't even sure that he could find a single person.'

I conclude that the number neutrality of Turkish PI requires a different explanation than the one for Hindi. My analysis will be built up in two steps: First, in Sect. 4, I will discuss how kind interpretation of bare singulars is derived. Then, in Sect. 5, I will argue that singular kind reference is the source of the number neutral readings of bare singulars in PI and the other two problematic cases.

\section{Kind reference in Turkish}

In this section, I discuss the properties of kind reference in Turkish and illustrate that the singular form of kind reference contrasts with the plural form in having an impure atomic nature. For this, I first discuss general properties of kind reference by introducing Turkish plural kind terms and then I analyze singular kind terms in a comparative way.

\subsection{Plural kind terms}

In Sect. 3.2, we have seen that Turkish bare plurals yield number neutral interpretations in downward entailing contexts and questions, based on which I have argued that they denote sets of atoms and their pluralities, as in English. As illustrated in Sect. 2, Turkish and English bare plurals are also equivalent in their ability to occur with kind-level and generic predicates, the examples of which are repeated here as (23a) and (23b). Additionally, Turkish and English bare plurals can have existential readings, as shown in (23c) (see Carlson 1977; Krifka et al. 1995; Chierchia 1998 for English). However, Turkish bare plurals can also be interpreted as definite unlike English bare plurals, as reflected in the translation of $(23 \mathrm{c})$.

a. Dinozor-lar 250 milyon yıl önce evrimleş-miş-tir.

dinosaur-PL 250 million year ago evolve-PERF-GEN

'Dinosaurs evolved 250 million years ago.'

b. Ayl-lar genelde saldirgan ol-ur.

bear-PL generally aggressive be-AOR

Footnote 20 continued

hand. While both singular and plural PI-ed nouns are compatible with the former, only the plural form is possible with the latter. Dayal argues that collection or gathering presupposes a plurality of sub-events of acquiring which might involve a single item at a time. The core process involved in comparison and uniting, though, requires a plurality at each sub-event. Since bare singulars do not provide this plurality, the result is infelicitous with these verbs. However, unlike in Hungarian, PI-ed bare singulars are compatible with compare and similar verbs in Turkish, providing further evidence that they can yield number neutral readings independent of the aspectual specification. See Sağ (2019) for details. 
'Bears are generally aggressive.'

c. Köpek-ler bugün çok havl1-yor.

dog-PL today very bark-PROG

'(The) dogs are barking a lot today.'

I will first illustrate how the readings that are available in both languages are derived, then turn to the definite reading of Turkish bare plurals.

The fact that bare plurals can be arguments of kind-level predicates like evrimleşmek 'evolve' or nesli tïkenmek 'be extinct' means that they have kind reference since such predicates only denote properties of kinds, individuals that identify classes of objects with a sufficiently regular function or behavior in nature (Carlson 1977). When we talk about natural kinds we not only refer to 'well-established' biological ones, but artifacts like books and cars, as well as more complex ones like intelligent students can be considered as kinds as well (Chierchia 1998, see also Krifka et al. 1995; Dayal 2004).

In Chierchia (1998), bare plurals in English are argued to start as type $\langle s,\langle e, t\rangle\rangle$ and become kind terms of type $\langle s, e\rangle$ via a nominalization operation (nom), shown in (24a). Nom is a function from properties to functions from situations $s$ to the maximal entity satisfying that property in that situation. That is, a kind, let us say the dinosaur kind, is an individual correlate of the property of being a dinosaur, as shown in (24b) (Chierchia 1998, p. 351).

a. For any property $P$ and world/situation $s$, where $P_{s}$ is the extension of $P$ in $s$ $\cap P=\left\{\begin{array}{l}\lambda s . \iota x\left[P_{s}(x)\right], \text { if } \lambda s . \iota x\left[P_{s}(x)\right] \text { is in } K, \text { the set of kinds } \\ \text { undefined, otherwise }\end{array}\right.$

b. $\cap$ dinosaur $=\lambda s . \iota x\left[\operatorname{dinosaur}_{s}(x)\right]$

Chierchia argues that the nom operator is only defined for plural properties, not singular properties. This is because if nom were applied to a singular property, it would mean that the kind is uniquely instantiated in every world/situation (Dayal 1992). However, this goes against the concept of a kind, which instead is identified with the totality of instances in any given world/situation.

Following Chierchia (1998)'s analysis, I take bare plurals in Turkish to be kind terms that are built on the corresponding property via nom. This makes it possible for them to directly combine with kind-level predicates, as in (23a), the denotation of which is given in (25).

$$
\llbracket(23 a) \rrbracket=\operatorname{evolved}\left(\lambda s . \iota x\left[\operatorname{dinosaur}_{s}(x)\right]\right)
$$

When plural kind terms combine with object-level predicates, they are type-shifted by the predicativization (pred) operator, which takes the extension of the kind (i.e., extension in whatever world/situation it is interpreted relative to) and returns the set of singular and plural entities that instantiate the kind (in that world/situation), as shown in (26) (Chierchia 1998, p. 350). In generic contexts, the Generic operator quantifies over these entities, as shown in (27) for (23b). 
(26) Let $d$ be a kind. Then for any world/situation $s$, where $d_{s}$ is the plural individual that comprises all of the atomic members of the kind

$\cup_{d}=\left\{\begin{array}{l}\lambda x . x \leq d_{s}, \text { if } d_{s} \text { is defined } \\ \lambda x . F A L S E, \text { otherwise }\end{array}\right.$

$$
\llbracket(23 b) \rrbracket=\text { Gen } s, x[\cup \cap \operatorname{bear}(s)(x)][\operatorname{aggressive}(s)(x)]
$$

When a kind-level argument combines with an object-level predicate in an episodic context, as in (23c), Derived Kind Predication (DKP) comes into the picture. DKP provides sort adjustment and introduces $\exists$-quantification over the instantiations of the kind provided by pred in a given situation, resulting in an existential reading, as shown in (28) (Chierchia 1998, p. 364).

$$
\begin{aligned}
& \text { a. DKP: If } P \text { applies to objects and } k \text { denotes a kind, then } P(k)=\exists x\left[{ }^{\cup} k(x)\right. \\
& \wedge P(x)] \\
& \text { b. } \llbracket(23 \mathrm{c}) \rrbracket=\text { barking.today }(\cap \operatorname{dog})=\exists x\left[{ }^{\cup \cap} \operatorname{dog}(x) \wedge \operatorname{barking} . \operatorname{today}(x)\right] \\
& \quad \text { (by DKP) }
\end{aligned}
$$

Bare plurals that have an existential reading take obligatory narrow scope. This is exemplified in (29), which conveys that there are no dogs barking today but not that there are some dogs that are not barking today. The latter would be possible if the plural could take scope over negation. This is predicted by the DKP analysis because the sort-adjusting $\exists$-quantification is introduced locally at the level of predication, i.e., inside the body of the abstract where the type-mismatch occurs, and therefore takes narrowest scope. So the interpretation in (29) is that there are no atomic or plural instantiations of the dog kind barking in the given situation.

\section{Köpek-ler bugün havla-mi-yor.}

dog-PL today bark-NEG-PROG

'Dogs aren't barking today.' (false if one or more dogs are barking today) $\neg$ barking.today $(\cap \operatorname{dog})=\neg \exists x\left[{ }^{\cup \cap} \operatorname{dog}(x) \wedge\right.$ barking.today $\left.(x)\right]($ by DKP)

The sentence in (23c) shows that Turkish bare plurals can also be definite in objectlevel contexts, and this also holds for (29). The explanation for this lies in the fact that Turkish does not have an overt definite determiner. A widely accepted view for languages without overt definite determiners is that their bare nouns can undergo covert iota type-shifting to gain definite interpretations. There are two principles in the neoCarlsonian approach that regulate the application of covert type-shifting operators: ${ }^{21}$

\section{a. Blocking Principle (Chierchia 1998):}

For any type shifting operation $\phi$ and for any $X$ : $* \phi(X)$ if there is a Determiner D such that for any set $X$ in its domain, $D(X)=\phi(X)$.

b. Revised Meaning Preservation (Dayal 2004) : $\{\cap, \iota\}>\exists$

\footnotetext{
21 I assume that Turkish bare nouns are NPs that undergo covert type-shifting. However, equivalent results can be obtained in a DP analysis with suitable adjustments to the Blocking Principle and Revised Meaning Preservation. The ranking in Revised Meaning Preservation is motivated by the fact that in languages without an overt definite determiner bare nouns can denote kinds as well as contextually salient unique entities, but they do not gain strong indefinite readings. See Dayal (2004) for details.
} 
According to Revised Meaning Preservation, type-shifters apply in a certain order, as long as the Blocking Principle is respected. The intuition behind the Blocking Principle is to ensure the use of lexical items before covert type-shifting operations are resorted to, for reasons of economy. This explains the difference between bare plurals in English and languages like Turkish in terms of definite interpretations. To be more precise, English and Turkish bare plurals can both shift via nom to yield kind-level readings, as laid out above. This is possible since nom is a high-ranked operator and there are no overt determiners in either language that would do the same job and hence block its application. ${ }^{22}$ However, only Turkish bare plurals can also shift via the covert iota operator and yield definite readings. Again, this is possible since iota is equally a high-ranked operator and Turkish does not have an overt definite determiner, unlike English where it is blocked by the. The low-ranked $\exists$-type shift does not come into play for bare plurals in either language, ruling out the possibility of strong indefinite interpretations.

We can thus derive the definite reading of (23c) as shown below:
a. $\iota: \lambda P . \iota x[P(x)]$ (the maximal member of $P$ if there is one, undefined otherwise)
b. $\llbracket k \ddot{o p p e k l e r} \rrbracket=\lambda x \cdot \operatorname{dog} s(x)$
c. $\iota(\llbracket k \ddot{o p p e k l e r} \rrbracket)=\iota x[\operatorname{dog} s(x)]$
d. $\llbracket(23 \mathrm{c}) \rrbracket=$ barking.today $(\iota x[\operatorname{dog} s(x)])$

In sum, bare plurals in Turkish, like bare plurals in English, become kind terms via nom, and receive object-level readings via pred and DKP. Unlike bare plurals in English, they can also undergo covert iota type-shifting to yield definite interpretations. We are now ready to explore how the stance taken here with respect to Turkish bare singulars fits in this picture.

\subsection{Singular kind terms}

In this section, I discuss singular kind terms and their differences from plural kind terms, which will prove to be in line with the strict singular view of bare singulars.

Just like bare plurals, bare singulars can also combine with kind-level and generic predicates, as illustrated in Sect. 2. The relevant examples are repeated in (32a) and (32b). However, in episodic contexts they are only interpreted as strictly singular and definite, as opposed to bare plurals, which, as we have seen, can receive narrow scope existential readings. Compare (32c) with (23c).

(32) a. Dinozor 250 milyon yıl önce evrimleş-miş-tir. dinosaur 250 million year ago evolve-PERF-GEN 'The dinosaur evolved 250 million years ago.'

b. Ayı genelde saldirgan ol-ur. bear generally aggressive be-AOR 'The bear is generally aggressive.'

\footnotetext{
22 I set aside cases with bare plurals that do not refer to kinds like parts of this machine (see Carlson 1977; Chierchia 1998; Dayal 2004, 2013).
} 
c. Köpek bugün çok havl1-yor.

dog today very bark-PROG

'The dog is barking a lot today.' Not: 'A dog is/Dogs are barking a lot today.'

The lack of the existential reading with bare singulars is further shown by their inability to take scope under negation, as in (33), where they have a singular and definite reading only. $^{23}$

Köpek bugün havla-mı-yor.

dog today bark-NEG-PROG

'The dog isn't barking today.' Not: 'A dog isn't/Dogs aren't barking today.'

In order to predict the lack of existential readings in (32c) and (33), I adopt Dayal's (2004) analysis of singular nouns, which I lay out below.

Dayal proposes that singular nouns are ambiguous in denoting properties of ordinary atomic individuals and properties of taxonomic atomic individuals, i.e., (sub-)kinds, the latter yielding kind-level interpretations as in 'The dinosaur is extinct.' Regulated by Revised Meaning Preservation and the Blocking Principle, this view immediately predicts a definite singular reading for bare singulars in Turkish, as in (32c) and (33), at the ordinary object level. The bare singular köpek, denoting a set of atomic dog individuals, undergoes iota type-shifting to refer to a unique contextually salient dog individual, as represented below for (32c):

$$
\begin{array}{ll}
\text { a. } & \llbracket k o ̈ p e k \rrbracket=\lambda x \cdot \operatorname{dog}(x) \\
\text { b. } & \iota(\llbracket k o ̈ p e k \rrbracket)=\iota x[\operatorname{dog}(x)] \\
\text { c. } & \llbracket(32 \mathrm{c}) \rrbracket=\operatorname{barking} . \operatorname{today}(\iota x[\operatorname{dog}(x)])
\end{array}
$$

In order to explain the denotation of singular nouns at the kind level, Dayal draws a distinction between singular and plural kind reference. She argues that although kinds overall are conceptually plural, singular kind terms are grammatically impure atomic terms. They differ from plural kind terms in not allowing type-shifting to sets of object-level entities.

Dayal draws an analogy with collective nouns like team and committee. Barker (1992) and Schwarzschild (1996) argue that such nouns are impure atomic group terms, unlike plural definites which denote sums, in the sense of Link (1983) and Landman (1989) (see also Kleiber 1990; Krifka et al. 1995; Zucchi and White 2001). Schwarzschild (1996) further shows that plural definites are compatible with recipro-

\footnotetext{
23 In the preverbal non-case-marked argument position, bare singulars seem to have a narrow scope existential reading. In Sects. 5.1 and 6.1, we will see that this is due to PI. What matters for us is that bare singulars cannot receive this reading when case-marked, contrasting with bare plurals. However, as also pointed out by a reviewer, profession/social role denoting bare singulars like ögrenci 'student' and ögretmen 'teacher' allow number neutral narrow scope existential readings in case-marked positions, like bare plurals: Ögrenci kütüphaneye uğramıyor artık. 'Students aren't going to the library anymore.' Notice, though, this interpretation is restricted: (i) The referents of these nouns have to be in abundance, massive in a sense, unlike DKP of bare plurals. (ii) It is only available in professional/report contexts. The sentence above gets an existential reading if it is uttered among teachers or it is a part of a report, for example. Since it would be misleading to generalize this restricted behavior to the broader class of bare singulars, I set aside these cases and refer the reader to Să̆ (2019) for more details.
} 
cals and distributive predicates like live in different cities, but collective nouns are not, as shown in (35) and (36). This suggests that groups do not allow distributivity over the individuals that they consist of, as opposed to sums.

a. The players/the team members live in different cities.

b. The players/the team members attacked each other.

a. \#The team lives in different cities.

b. \#The team attacked each other.

The group term team and the definite plural the players/the team members are conceptually associated with the same set of entities, i.e., players (a, b, c) and their pluralities $(\mathrm{a} \oplus \mathrm{b}, \mathrm{a} \oplus \mathrm{c}, \mathrm{b} \oplus \mathrm{c}$, and $\mathrm{a} \oplus \mathrm{b} \oplus \mathrm{c})$, but their relation to these entities differ. The definite plural has them as its parts, represented by the part-of relation $\leq$, but the group term has them as its members, represented by $\downarrow$ in Landman (1989). In other words, while groups are atomic elements that have no internal structure, they still retain the relation that they hold with their individual members.

Dayal treats plural kind terms as sums, which hold a part-of relation to the individuals instantiating the kind. This is reflected by $\leq$ in pred (see (26) above). In contrast, she considers singular kind terms to be like groups, and claims that the relation between singular kinds and the specimens remains at the conceptual level. Unlike plural kind terms which are derived from a relevant property, singular kind terms directly refer to kinds in the taxonomic domain. ${ }^{24}$

Singular kind terms are derived compositionally from the regular definite determiner and a singular noun that denotes an atomic property of taxonomic individuals, i.e., (sub-)kinds: $\iota X[P(X)], X$ ranging over entities in the taxonomic domain. Similarly, other determiners like every and $a$, as well as numerals also yield taxonomic readings when they combine with taxonomic properties. Consider (37) (Dayal 2004, pp. 423, 424): (Adopting the convention in Dayal (2004), from now on singular kinds will be represented with capital letters.)
a. The African lion is extinct.
b. Every/a/one lion is extinct.
c. Two lions are extinct.

In (37), the domain of quantification is the sub-kinds of the species lion for the predicate is a kind-level predicate. That is, the predicate $L I O N$ denotes the sub-kinds AFRICAN LION, ASIATIC LION, etc. (37a) differs from (37b) and (37c) in that the existence of the definite determiner imposes a uniqueness requirement. In (37a), the taxonomic property $L I O N$ combines with the taxonomic property $A F R I C A N$ the denotation of which includes all the African kinds, including AFRICAN LION. Their intersection yields the singleton set $\{A F R I C A N L I O N\}$, which refers to the unique African lion kind through its combination with the definite determiner.

\footnotetext{
${ }^{24}$ Landman (1989) also posits an operator that forms groups from sums, represented by $\uparrow$. Dayal's view departs from this in the treatment of taxonomic kinds as distinct entities that are not derived from a property correlate.
} 
Singular kind reference is also possible if the domain of quantification only includes distinct kinds. In (38), for example, the domain of quantification is the set of taxonomic entities given in (38a), which does not include the sub-kinds of lions, but instead some distinct kinds like $L I O N$, WHALE, etc. In that case, the extension of the taxonomic predicate $L I O N$ is a singleton set whose only member is the taxonomic individual $L I O N$, as shown in (38b). The combination of the property LION with iota ensures the reference to the unique lion kind. What level of the taxonomic hierarchy (i.e., kinds or their sub-kinds) will be relevant to the interpretation of taxonomic properties is determined by the context (Dayal 2004, p. 426).

The lion is extinct.

a. $U_{c}=\{L I O N$, WHALE,$D O G\}$

b. $\llbracket l i o n \rrbracket=\{L I O N\}$

c. become-extinct $(\iota X[\operatorname{LION}(X)])$

Following Dayal's view of singular kind reference, I claim that Turkish bare singulars also have a taxonomic property denotation in addition to the ordinary object-level one. Due to the lack of a definite determiner in Turkish, though, reference to a unique kind individual is ensured by covert iota type-shifting. When a bare singular combines with a kind-level predicate, as in (32a), its taxonomic denotation is at play, as shown below:
a. $\llbracket$ dinozor $\rrbracket=\lambda X . \operatorname{DINOSAUR}(X)$
b. $\iota(\llbracket$ dinozor $\rrbracket)=\iota X[\operatorname{DINOSAUR}(X)]$
c. $\llbracket(32 \mathrm{a}) \rrbracket=$ evolved $(\iota X[\operatorname{DINOSAUR}(X)])$

In a nutshell, I claim that Turkish bare singulars are interpreted as follows:

III. Turkish bare singulars are ambiguous in denoting an atomic property of objectlevel entities and an atomic property of taxonomic/kind entities. Undergoing iota type-shifting, they can either be definite singulars or singular kind terms.

As illustrated in (32c) above, bare singulars lack a narrow scope existential reading, contrasting with bare plurals. This is predicted since singular kind terms, having an impure atomic nature, do not allow type-shifting to the object-level entities that we intuitively associate with them. The kind-driven existential reading, though, is dependent on this shift, which is ensured for plural kind terms by pred when DKP applies.

The fact that bare singulars in their kind reading refer to impure atomic kinds, as opposed to bare plurals, is evidenced by their interaction with distributive elements. Above, we have seen that object-level group terms do not lend themselves to distributive predication and the same applies to singular kind terms. As shown in (40), the singular kind term ayı, as opposed to the plural kind term ayılar, is incompatible with predicates like come from different regions in episodic statements. Note that the same contrast also holds in English, as reflected in the translations.

(40) Ayı*(-lar) bu hayvanat bahçesi-ne farklı bölge-ler-den gel-di. bear-PL this zoo-DAT different region-PL-ABL come-PAST 'Bears/*The bear came to this zoo from different regions.' $\exists x\left[\cup \cap \operatorname{bear}(x) \wedge \forall y, z\left[[y<x \wedge z<x \wedge y \neq z] \rightarrow \operatorname{ir} 1\left[\right.\right.\right.$ region $\left(r_{1}\right) \wedge$ came.to.zoo.from $\left.\left(r_{1}\right)(y)\right] \neq \iota r_{2}\left[\operatorname{region}\left(r_{2}\right) \wedge\right.$ came.to.zoo.from $\left.\left.\left.\left(r_{2}\right)(z)\right]\right]\right]$ 
The contrast in (40) arises as follows: The singular kind term ayl 'the bear' is an impure atomic term, and hence cannot be type-shifted into sets of object-level entities. Since come from different regions is a distributive predicate, requiring access to different parts of these entities, the derivation fails when the two are combined. However, plural kind terms grant access to their instantiations for distributivity. As shown in the truth condition represented above, the plural kind term is type-shifted via pred, denoting a set of singular and plural entities instantiating the kind in the relevant situation. The predicate distributes over these instantiations. $^{25}$

Let us now consider the following paradigm to understand better how the impure atomicity of singular kind terms plays a role in object-level contexts.
a. The dog is barking.
b. The rat arrived in Australia in 1770 .
c. The buffalo is roaming the prairie again.

The sentence in (41a) is a statement about a unique contextually salient dog, where the singular noun $d o g$ denotes a set of ordinary dog individuals. In contrast, although (41b) can be a statement about a unique rat individual as well, the salient reading involves reference to the rat kind. In order for (41b) to be true on this reading one or more rats should have the property at issue, but there is something more that is implied. The individual rats involved in the event stand in for the whole species as a singleton individual. This is known in the literature as the representative object reading but what exactly is involved in such readings has never been formalized (see Krifka et al. 1995). I will not attempt to formalize it here, either. However, there are some crucial features of these readings that we can use to guide us.

One can understand the representative object reading better in relation to the DKP-derived existential reading of bare plural kind terms. Although both require the involvement of some object-level entities in their truth conditions, the representative object reading of singular kind terms differs from DKP-based reading of bare plurals. While in DKP the protagonist of the event is some instantiation of the kind, in the representative object reading, it is the kind individual itself. One can think of the latter as involving the total participation of the species or as involving some type of radical change of state for the species (p.c. Veneeta Dayal and Gennaro Chierchia). For example, in (41b), arriving in Australia is a property of the total rat kind, not just some rat individuals, and (41c) is only acceptable as a statement about buffalos if at a prior time, the species had become extinct or at least near-extinct. The episodic statement can then be read as a change of state from near extinction to the one of prosperity. ${ }^{26}$ On the other hand, (41a) does not have a representative object reading since the predication expresses an episodic event of a dog individual being engaged

\footnotetext{
25 Notice that iota type-shifting applies at the level of both ordinary objects and kind entities. In (40), $\iota r_{1}\left[\right.$ region $\left.\left(r_{1}\right)\right]$ and $\iota r_{2}\left[\right.$ region $\left.\left(r_{2}\right)\right]$ both refer to a unique region at the domain of ordinary objects. The distinction between taxonomic and object-level entities is represented via capital vs. small letters in this paper.

26 The fact that the representative object reading requires the involvement of some object-level entities in its truth conditions does not mean that type-shifting to sets of object-level entities takes place. The kind-level predicate be extinct also requires the involvement of object-level entities in its truth conditions. For a kind to be extinct, the object-level entities associated with the kind need to die, yet the property is attributed to the kind, not to these entities. The representative object reading is similar in this respect, except that it
} 
in a barking action, and this event is not momentous enough for it to be attributed to the whole dog kind.

Another difference between the representative object reading and the DKP-derived existential reading is revealed by the fact that a definite singular kind term cannot lend itself to iterative readings in the same way that a plural kind term can. The statement in (42a), from Dayal (2011), is about different instantiations of the mouse kind engaging in distinct events of entering. This reading is derived since plural kind terms, undergoing DKP, can be type-shifted to denote sets of entities instantiating the kind in the relevant situation. This makes it possible for each entering event to involve different parts of these entities. In contrast, singular kind terms do not allow such interpretations in virtue of their impure atomicity. Therefore, (42b) can only be about a single mouse that engages in the same event multiple times, which is derived through the ordinary object-level denotation of the singular noun instead.

a. Mice kept entering the room.

b. The mouse kept entering the room.

Based on these differences, I take the representative object reading, as in (41b) and (41c), to be distinct from the DKP-based readings of plural kind terms, as in (42a). The nature of this reading will be clarified further in Sect. 6.1, but for now I adopt the following generalization reached in Dayal (2004): Singular kind terms are compatible with episodic contexts only if they stand for the whole species as a singleton representative/prototypical entity. This corresponds to singularity in syntactic terms, but they remain true to the notion of kind, being conceptually plural (cf. Jespersen 1927; Langford 1949; Carlson 1977; Heyer 1985, and Krifka et al. 1995).

Then, as in English, when a singular kind term in Turkish refers to the species under the representative object reading, its taxonomic denotation comes into play. This is shown in (43):

$$
\begin{aligned}
& \text { Bilgisayar bu ülke-ye çok geç gel-di. } \\
& \text { computer this country-DAT very late come-PAST } \\
& \text { 'The computer reached this country very late.' } \\
& \text { reach.this.country.late }(\iota X[\operatorname{COMPUTER}(X)])
\end{aligned}
$$

Similarly, singular kind terms are acceptable in generic sentences if they refer to the whole species via a singleton representative entity per situation, as exemplified in (32b). The fact that singular kind terms block access to the object-level entities is also visible in generic contexts, as shown by the distributivity test. ${ }^{27}$ While the bare plural is compatible with the reciprocal which distributes over singular and plural entities

\footnotetext{
Footnoot 26 continued

requires only a representative subset of object-level entities to participate in the event for the property to be attributed to the whole kind.

${ }^{27}$ Unlike (44), the generic version of the singular form in (40) is accepted by some speakers: $A y l$ bu hayvanat bahçesine farklı bölgelerden gelir. 'The bear comes to this zoo from different regions.' However, this sentence does not express generic situations, each of which consists of bears coming from different regions. Rather, the distributivity is over the situations/events that the generic operator quantifies over. So, in situation 1, they come from Asia, in situation 2, from Africa, etc. This is expected given the impure atomic nature of singular kind terms.
} 
instantiating the kind, the bare singular is not compatible with it due to its impure atomicity. ${ }^{28}$

$$
\begin{aligned}
& \text { Kedi*(-ler) birbiri-ne saldır-1r. } \\
& \text { cat-PL each.other-DAT attack-AOR } \\
& \text { 'Cats attack each other./*The cat attacks each other.' } \\
& \text { Gen } s, x[\cup \cap \operatorname{cat}(s)(x)][\forall y, z[[y<x \wedge z<x \wedge y \neq z] \rightarrow \operatorname{attack}(s)(y)(z)]]
\end{aligned}
$$

To summarize, we can predict all the attested readings of bare nouns in Turkish within the neo-Carlsonian approach to bare nouns and the analysis of kind terms adopted here. As in English, Turkish bare plurals are kind terms whose object-level readings are derived via pred and DKP. Unlike English bare plurals, they can also be type-shifted via iota and have definite readings, due to the lack of an overt definite determiner. Turkish bare singulars are ambiguous in denoting atomic properties of ordinary individuals and atomic properties of (sub-)kinds. In kind-level contexts, their kind-level property denotation shifts via iota to yield singular kind readings. In object-level contexts, their ordinary individual property denotation shifts via iota to yield singular definite readings. English singular nouns only differ in that they combine with the overt definite determiner in these cases.

I now turn to the distinctive status of singular and plural kinds. We have seen the arguments for distinguishing between them with respect to their relationship to the ordinary entities that they are conceptually connected to. In formal terms we can posit two separate relations to explain the differential behavior of singular and plural terms. Drawing on the familiar analogy to sums and groups, I adopt the view that the relation that plural kinds stand in with their instantiations is separate from the relation singular kinds stand in with the individuals that we intuitively associate with them. I represent the latter as a belong-to relation, as shown below:

\section{Belong-to relation}

belong-to $\left(y, x^{K}\right)$ is true iff $y$ is a member of the kind $x^{K}$, where $x^{K}$ is a singular kind and $y$ is an object-level entity.

To see the belong-to relation in action, consider the example in (43). The first computers that were brought to the country conceptually hold a belong-to relation to the kind that they represent, i.e., the computer kind. In other words, they are members of the computer kind.

On the other hand, plural kinds are related to their instantiations via pred, and we can parse that relation in terms of an instantiation-of relation, as shown below, to make transparent the difference with the belong-to relation in (45). Crucially, although singular and plural kinds are associated with the same set of atomic and plural entities, their relation to these entities differ. Plural kinds have them as their parts, singular kinds have them as their members.

\footnotetext{
28 Notice that in the plural form of (44) the most salient reading involves distributivity down to atomic instantiations of the kind, while in (40) the most salient reading involves distributivity to pluralities. I set aside the reasons for this variation, as it is orthogonal to the point under discussion (see Dalrymple et al. 1994 for the relevant discussion). The important point for present purposes is that plural kind terms make individual instantiations available for distributive predication, contrasting with singular kind terms.
} 


\section{Instantiation-of relation}

a. instantiation-of $\left(y, x^{k}\right)$ is true iff for any world/situation $s, y \leq k_{s}$, where $x^{k}$ is a plural kind, $y$ is an object-level entity, and $k_{s}$ is the plural individual that comprises all of the atomic instances of the kind $x^{k}$ in $s$.

b. $x \leq z$ is true iff $x \sqcup z=z$, where $\sqcup$ denotes the join operation on the domain of individuals.

Although the instantiation-of relation is established via pred, there is no typeshifting operator that establishes the belong-to relation in the grammatical component. Namely, an operator that takes a singular kind term and returns a set of individuals that belong to its referent (i.e., $\lambda x^{K} \lambda y$. belong-to $\left(y, x^{K}\right)$ ) is not available at LF. Thus, although singular kinds are conceptually related to their specimens, this relation is not represented in the grammatical component, as Dayal (2004) claims; at least not in the same way as the instantiation-of relation is represented. I argue however that there are two constructions in Turkish where the belong-to relation is operative in the grammar; one is pseudo-incorporation and the other happens in the predicate position. This more extensive use of singular kind reference in Turkish is the factor that separates Turkish bare singulars from English singular nouns in terms of number neutral readings. I illustrate the details next.

\section{Explaining number neutrality of bare singulars}

Now that we have the ontological machinery in place, I turn to the three cases in which Turkish bare singulars have number neutral readings: the non-case-marked direct object position, the existential copular construction, and the predicate position. In Sect. 3.3, I have categorized the first one as an instance of pseudo-incorporation (PI). I will now elaborate on the explanation for this phenomenon, extending it to the other two cases as well. I will illustrate that the number neutral reading of bare singulars in these cases is derived from their kind-level characteristics.

\subsection{Pseudo-incorporation with singular kind terms}

I argue that PI in Turkish denotes sub-event types in line with Dayal (2011, 2015), but with singular kind arguments rather than as property denoting nouns in the direct object position. I further argue that the number neutral reading is ensured through an incorporating thematic function that takes a singular kind term and forms a belong-to relation between the thematic argument of the verb and the referent of the kind term.

I start by discussing the similarities between Turkish PI-ed bare singulars and English weak definites and then build my analysis for Turkish PI based on this analogy. I further illustrate that subject PI is also possible in Turkish, following Öztürk (2005), which I will extend to bare singulars in the existential copular construction in Sect. 5.2 . 


\subsubsection{Analogy with English weak definites}

It has been noted that singular nouns do not always yield strictly singular readings even in English. This is observed with the so-called weak definites, which are not associated with uniqueness despite the presence of a definite determiner. For example, (47a) could be true in a situation where I read one or multiple newspapers when I get home, and (47b) could mean that Mary took train A halfway to Brussels, and train B for the other half.

a. I will read the newspaper when I get home.

b. Marry took the train to Brussels.

(Carlson and Sussman 2005, p. 2)

(Carlson 2006, p. 8)

Motivated by this fact, Carlson and Sussman (2005) and Carlson (2006) analyze English weak definites as a case of PI. Building on these works, Bosch and Cieschinger (2010), Aguilar-Guevara and Zwarts (2010), and Schwarz (2014) offer different analyses. Aguilar-Guevara and Zwarts show that weak definites have a narrow scope reading, as in (48), where the hospital allows a distributive interpretation. Crucially for us, they also show that only sub-type forming adjectives are acceptable with the weak definite reading, as shown in (49) (pp. 180-181).

(48) Every boxer was sent to the hospital.

(49) a. \#Lola is in the new hospital vs. $\checkmark$ Lola is in the medical hospital.

b. \#You should see the doctor who works in the medical center. vs. $\checkmark$ You should see the eye doctor.

They further point out that the weak definite reading requires stereotypical circumstances to hold. For example, in Alice went to the hospital, it does not suffice for Alice to merely go to a hospital; she also needs to be engaged in a stereotypical activity there, like undergoing an examination or working as a doctor. This means that weak definites obey name-worthiness.

The behavior of weak definites as laid out above is very similar to PI, but only certain nouns can form weak definites. To give an example, while both newspaper-reading and book-reading are available in Turkish PI, the weak definite reading is restricted to the former in English. I argue that Turkish PI and English weak definites should be analyzed in a unified way based on the striking similarities between the two (cf. Dayal 2015). However, the highly productive status of Turkish PI makes the number neutrality associated with these phenomena more visible in Turkish than in English.

Aguilar-Guevara and Zwarts analyze weak definites as singular kind terms in light of Dayal's (2004) view of singular kinds and link the restriction in modification to this view. Being built on taxonomic properties, weak definites can only receive modification that is taxonomic in meaning. It follows then that only adjectives establishing sub-kinds would be acceptable with the weak definite reading. For example, the adjective new in (49) is considered as operating at the level of ordinary objects since the new hospital does not easily denote a type of the hospital kind for that particular event. In contrast, the adjective medical can be considered as operating at the taxonomic domain since medical hospitals are types of hospitals. 
I now apply this view to Turkish PI: In Sect. 2, we have seen that a similar restriction in modification is observed in the non-case-marked direct object position, constituting one of the core puzzles regarding the number interpretation of bare singulars. As repeated in (50), while religious/scientific book-reading is a good candidate for PI, the modification of book with old/small is not available in the non-case-marked direct object position:

a. Ali, ev-e geldikten sonra, dinil bilimsel kitap oku-du. Ali home-DAT having.come after religious scientific book read-PAST 'After he came home, Ali read one or more religious/scientific books.'

b. *Ali, ev-e geldikten sonra, eskil küçük kitap oku-du. Ali home-DAT having.come after old small book read-PAST 'After he came home, Ali read one or more old/small books.'

This contrast is compatible with treating PI-ed bare singulars as singular kind terms, considering that religious and scientific are sub-type forming/classificatory adjectives as opposed to old (worn-out) and small which denote object-level properties of books instead. However, the restriction in modification does not necessarily have to follow from the singular kind analysis. Dayal $(2011,2015)$ observes that the modification of PI-ed nouns is subject to similar constraints in Hindi and explains it as an effect of the name-worthiness requirement of PI, which she further treats as a presupposition. That is, PI is only defined if the PI-ed noun denotes a prototypical theme for the activity associated with the verb resulting in a canonically recognizable sub-type of the activity. For example, in Hindi old book-selling is possible, unlike heavy book-selling, because old books, but not heavy books, can be a prototypical theme for the selling activity, for instance in a second-hand book store context. So, the modification facts still hold when PI happens with ordinary object-level properties, as in Hindi.

However, the singular kind analysis captures the fact that PI-ed bare singulars yield a number neutral reading independent of the aspectual specification in Turkish. This is possible due to the relation that holds between a grammatically atomic kind term and the singular and plural individuals that belong to the species. ${ }^{29}$

I thus make the following claim regarding the semantics of PI-ed bare singulars:

IV. Turkish PI-ed bare singulars are singular kind terms and they can therefore only be modified by sub-kind denoting, i.e., taxonomic, adjectives.

What taxonomic modifier is compatible with the PI-ed singular kind term is determined by the name-worthiness requirement, which I take to be a presupposition, following Dayal (2011, 2015). In other words, for PI to be defined, the modification of the singular kind term should ensure reference to the kind that a prototypical theme argument of the verb is a member of.

\footnotetext{
29 Dayal (2015) notes that telicity cannot guarantee a singular reading with English weak definites. This confirms their parallelism with Turkish PI. However, Dayal also notes some respects in which English weak definites depart in behavior from PI-ed nouns.
} 
The explanation for the contrast in (50) is then as follows: The bare singular book in (50a) is a PI-ed singular kind term, so it can only be modified by taxonomic adjectives. Similarly to how singular nouns are ambiguous in having object-level and taxonomiclevel denotations, some adjectives can function as taxonomic modifiers depending on both the noun being modified and the context, in addition to functioning as a modifier at the ordinary object-level domain. Religious and scientific are two such adjectives, and in (50a) they operate at the taxonomic domain by name-worthiness. That is, intersecting with the taxonomic property $B O O K$, they denote a sub-kind of the book kind, i.e., the religious/scientific book kind, the members of which constitute a prototypical theme for the reading activity.

In contrast, the adjective old with a meaning like worn-out and the adjective small do not establish a type of the book kind in a reading context, and as such, they can only operate at the level of ordinary objects. Given that bare singulars in the non-casemarked direct object position are instances of PI and PI-ed bare singulars are singular kind terms, these adjectives cannot modify the bare singular book and be a part of PI in (50b). ${ }^{30}$ For the same reason, the bare singular book in (50a) cannot receive a strict singular interpretation.

We do not observe similar effects with case-marked bare singulars when they have a definite singular reading. This is predicted since bare singulars do not undergo PI in the case-marked argument positions, and therefore denote at the ordinary object level this time. So all adjectives, including religious and scientific, also denote properties of object-level entities when they modify these nouns, and hence no contrast arises in number interpretation. ${ }^{31}$

In sum, I claim that PI-ed bare singulars in Turkish are singular kind terms, similar to weak definites in English. Below, I show how they participate in PI. While the account I develop is specific to Turkish, it has obvious implications for English weak definites as well.

\subsubsection{Pseudo-incorporation in Turkish}

I argue that Turkish PI-ed bare singulars are both semantic and syntactic arguments of the verb. We know that they are semantic arguments since they bear a thematic role on them; they denote the theme of the activity associated with the verb. However, their

\footnotetext{
30 See Sağ (2019) for how a more complex form of taxonomic modification is derived. Furthermore, objectlevel modification of a non-case-marked bare singular is possible in generic contexts: Ali genellikle eski kitap okur. 'Ali generally reads old books.' Revised Meaning Preservation, which ranks iota above $\exists$-type shift, predicts that eski kitap 'old book' will receive a definite singular reading. In an episodic context, this requires accusative case-marking on the noun, but in the generic case, number neutrality arises since the singular term is in the restrictor of the Generic operator. Quantification in this case is over situations, each of which has a unique old book in it. The uniqueness effect is therefore diluted. The lack of case-marking on the noun might be a reflection of this effect.

31 As discussed in Sect. 4.2, besides denoting at the object level, case-marked bare singulars can also be singular kind terms when they occur with kind-level predicates or receive a representative object reading. When this is in evidence, they are only compatible with taxonomic modifiers, similar to PI-ed singular kind terms. We will discuss the differences between case-marked and non-case-marked singular kind terms in Sect. 6.1.
} 
syntactic argument status is harder to identify because, as mentioned in Sect. 3.3, PI-ed bare singulars have some differences from canonical arguments. That is, they do not bear case-marking on them and they are required to be adjacent to the verb. Despite their non-canonical properties, PI-ed bare singulars must also be syntactic arguments for two reasons:

First, it is impossible to add an extra object with the same thematic role to the structure, as shown in (51), which would be expected if PI-ed bare singulars did not occupy the direct object position of the verb (Öztürk 2005, p. 111). This contrasts with PI in Chamorro, where theme-doubling is possible (Chung and Ladusaw 2004).
*Ali Romeo ve Juliet(-i) kitap oku-du.
Ali Romeo and Juliet-ACC book read-PAST
Literally intended: 'Ali did book-reading Romeo and Juliet.'

The other argument in favor of treating PI-ed bare singulars as bona fide syntactic arguments of the verb comes from its impact on case marking in causative structures. PI-ed bare singulars behave like accusative case-marked direct objects in that they block the assignment of accusative case to other arguments in these structures. Öztürk (2005) shows this via a contrast with unergative constructions. When an unergative verb, which lacks an object position, is causativized, the agent (the causee) receives accusative case-marking, as in (52a). However, when a transitive verb, which has an accusative case-marked direct object, is causativized, the agent receives dative casemarking, as in (52b). Crucially, when an incorporating verb is causativized, the agent receives dative case-marking as is the case with transitive verbs, as shown in (52c) (Öztürk 2005, p. 109). This demonstrates that PI-ed bare singulars still function as a direct object although they do not bear case marking on them. Otherwise, we would expect incorporating verbs to pattern with unergative verbs when causativized. This contrasts with Hindi PI-ed nouns which are argued to denote a property that modifies the verb. ${ }^{32}$
a. Ayşe Ali-yi koş-tur-du.
Ayşe Ali-ACC run-CAUS-PAST
'Ayşe made Ali run.'
b. Ayşe Ali-ye/*-yi balı̆̆-1 tut-tur-du.
Ayşe Ali-DAT/ACC fish-ACC catch-CAUS-PAST
'Ayşe made Ali catch the fish.'
c. Ayşe Ali-ye/*-yi balık tut-tur-du.
Ayşe Ali-DAT/ACC fish catch-CAUS-PAST
'Ayşe made Ali go fishing.'

Although PI-ed bare singulars are full-fledged arguments, they still need to be kept apart from case-marked arguments. For this, I follow Öztürk (2005) in that the verbal structure has two distinct domains: The lexical domain of VP where case-assignment does not occur and the VP external functional domain where canonical arguments are

\footnotetext{
32 See also Espinal and McNally (2011) for a variant in which a PI-ed noun is a nominal modifier of the verb.
} 
introduced and assigned case. ${ }^{33}$ I take the fairly strict word order restrictions of PI-ed bare singulars to be a result of their being in the VP internal domain. ${ }^{34}$

Adopting a line of thinking in neo-Davidsonian terms, I argue that PI occurs through an Inc head that introduces an incorporating function, i.e., Inc. It merges with a theme head, i.e., Th, that introduces the theme function $T h$, and creates an incorporating theme head, i.e., $\mathrm{Th}_{I N C}$, that introduces a special incorporating theme function, i.e., $T h_{I N C}$. The complex $\mathrm{Th}_{I N C}$ head merges with the verb and creates a complex verbal head, which takes a bare singular as its complement. Namely, PI occurs inside the VP internal domain. I call the case-assigning heads little $v$ theme and little $v$ agent, represented as $v_{T h}$ and $v_{A g}$.

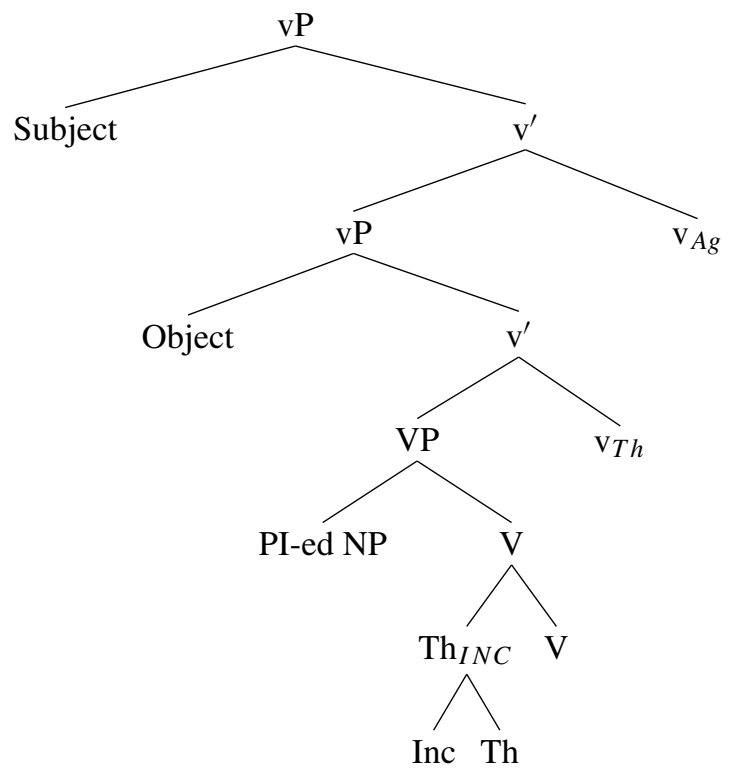

Taking verbs to denote properties of events $e$, of type $\langle v\rangle$, I define Inc as a function that takes the $T h$ function of type $\langle\langle v, t\rangle,\langle e,\langle v, t\rangle\rangle\rangle$ and returns a new $T h_{I N C}$ function of type $\left\langle\langle v, t\rangle,\left\langle e^{K},\langle v, t\rangle\right\rangle\right\rangle$. Th $h_{I N C}$ takes a verb and a singular kind term to denote a predicate of events whose theme is a member of the kind the singular kind term refers to. In short, it restricts the domain of individuals that the $T h$ function can combine with to singular kind arguments only, and forms a belong-to relation between the theme of the event and the referent of the kind term:

$$
\begin{aligned}
& \text { a. } \llbracket T h \rrbracket=\lambda V_{\langle v, t\rangle} \lambda x \lambda e . V(e) \wedge T h(e)=x \\
& \text { b. } \llbracket I n c \rrbracket=\lambda Q_{\langle\langle v, t\rangle,\langle e,\langle v, t\rangle\rangle\rangle} \lambda V_{\langle v, t\rangle} \lambda x^{K} \lambda e . \exists y\left[\text { belong-to }\left(y, x^{K}\right) \wedge Q(V)(y)(e)\right]
\end{aligned}
$$

\footnotetext{
33 The representation in (53) is somewhat different from Öztürk's. She argues that thematic role assignment only occurs in the functional domain and a PI-ed object receives its theme role by undergoing head-movement together with the verb to the theme-introducing functional head (represented as $v_{T h}$ here). However, it is not obvious how the interpretation would be derived compositionally on her account.

34 The VP internal position is not only dedicated to PI, but in fact hosts non-specific direct object arguments in general. We discuss this in Sect. 6.2.
} 
c. $\llbracket T h_{I N C} \rrbracket=\llbracket I n c \rrbracket(\llbracket T h \rrbracket)=\lambda V_{\langle v, t\rangle} \lambda x^{K} \lambda e . \exists y\left[\right.$ belong-to $\left(y, x^{K}\right) \wedge V(e) \wedge$ $T h(e)=y]$

Eventually, the predicate of events denoted by the saturation of the verb and the singular kind argument to $T h_{I N C}$ is a sub-type of the event denoted by the verb. The incorporation is defined iff the application of $T h_{I N C}$ to the verb and its singular kind argument denotes a canonically recognizable type of event (i.e., name-worthiness).

In a nutshell, I make the following claim with regard to PI of singular kind terms in Turkish:

V. Turkish PI takes place in the lexical domain of VP where case assignment does not occur. It is achieved with an incorporating thematic function that establishes a belong-to relation between singular kinds and individuals that belong to these kinds. The establishment of this relation is what makes it possible for bare singulars to receive a number neutral interpretation in the non-case-marked direct object position.

Here is how Ali kitap okudu. 'Ali did book-reading.' is derived: Syntactically, the singular kind term book is introduced inside the VP and remains non-case-marked, and the agent argument $A l i$ is introduced in the functional domain and receives nominative case. Ignoring tense, the semantic derivation is illustrated in (55). The derivation is existentially closed, as shown in (56).

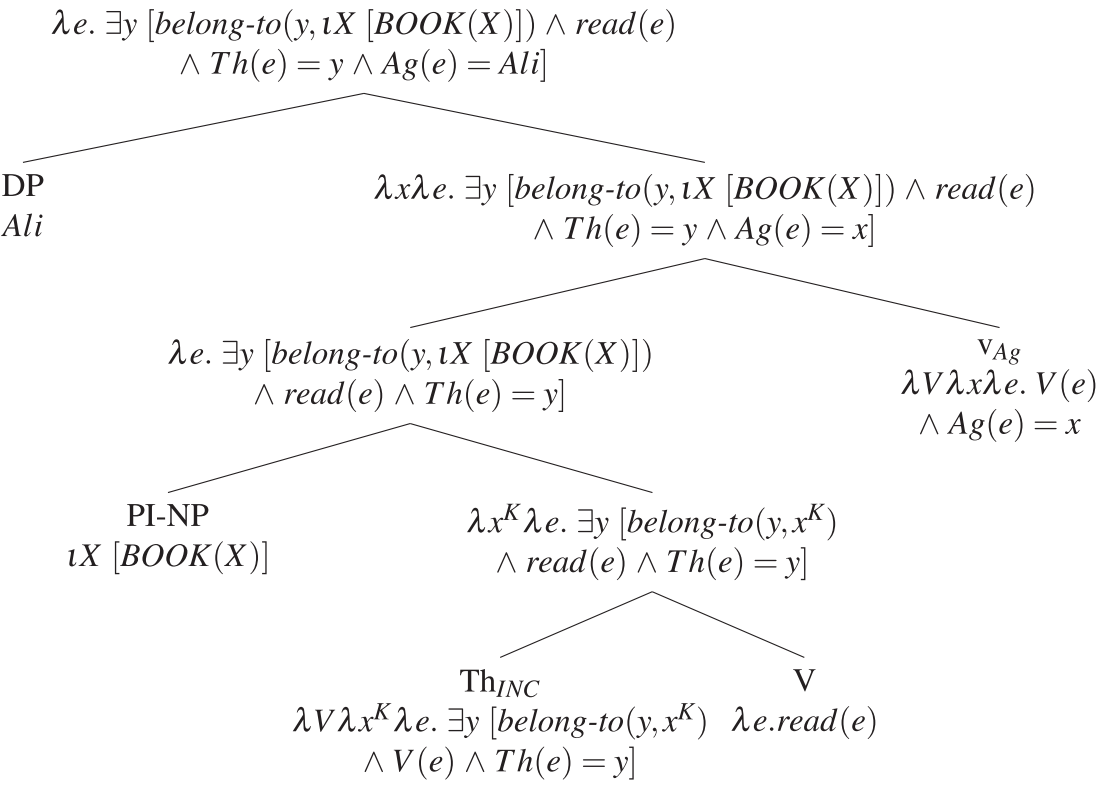

Informally, (56) means that Ali is involved in a book-reading event type as an agent. A book-reading event type is a reading event with a theme argument that belongs to 
the book kind. Since the members of a kind can be both atomic (a book) and plural individuals (books), PI yields a number neutral interpretation. ${ }^{35}$

Canonical arguments, in contrast, are introduced in the functional domain by regular thematic functions and receive case. For example, the bare singular kitap 'book' in (57a) denotes an atomic property at the ordinary object level and undergoes iota typeshifting to denote a contextually salient unique book individual, as shown below. It is introduced in the spec of $\mathrm{v}_{T h}$ as a theme argument via the canonical $T h$ function. As a result, it receives accusative case.

a. Ali kitab-1 oku-du.

Ali book-ACC read-PAST

'Ali read the book.'

b.

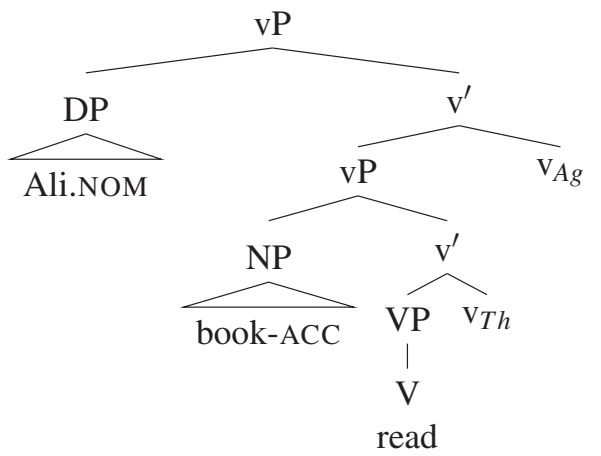

c. $\exists e[\operatorname{read}(e) \wedge T h(e)=\imath x[\operatorname{book}(x)] \wedge A g(e)=A l i]$

PI yields a narrow scope reading since the theme of the event is introduced through an $\exists$-quantification over the entities that belong to the singular kind as part of the $T h_{I N C}$ function. When $T h_{I N C}$ is applied to the verb, the $\exists$-quantification becomes a part of the event meaning. The narrow scope then results from the event quantifier always taking narrow scope with respect to other quantificational elements. For example, (58) means that there is no reading event with an entity that belongs to the book kind as its theme that Ali is involved in as an agent.

\footnotetext{
35 Aguilar-Guevara and Zwarts (2010) argue that weak definites, being singular kind terms, stand in Carlson's (1977) Realization relation $(R)$ with the implicit theme of the verb (cf. Espinal and McNally 2011; Schwarz 2014). $R$ is the realization relation between kinds and their instantiations which is later defined as pred in Chierchia (1998). My analysis separates the relation which singular kinds hold with respect to the specimens from the one associated with plural kinds, and captures the empirical differences between the two forms of kind terms discussed in Sect. 4.2. Furthermore, differing from Aguilar-Guevara and Zwarts's account, the belong-to relation is accompanied by an $\exists$-quantification over the members of the kind. They avoid the $\exists$-quantification because weak definites do not introduce discourse referents at the ordinary object level. As pointed out in fn (18), this paper does not address the (non)referentiality issue of Turkish PI, and as observed in Seidel (2020a, b), there are both cases where PI-ed bare singulars introduce discourse referents and cases where they do not. Completely avoiding $\exists$-quantification leaves the former unexplained, while allowing it seems to be a problem for the latter. I leave this issue for future research. See also Krifka and Modarresi (2016) who observe similar inconsistencies in Persian.
} 
Ali kitap oku-ma-di.

Ali book read-NEG-PAST

'Ali didn't do book-reading.' (no books)

$\neg \exists e \exists y[$ belong-to $(y, \iota X[B O O K(X)]) \wedge \operatorname{read}(e) \wedge T h(e)=y \wedge A g(e)$

$=A l i]$

Note that PI and DKP are very similar but that they are not the same phenomena. DKP is built on the instantiation operator pred which is always available whenever plural kind terms occur with object-level predicates. Thus, DKP does not have positional restrictions. It can occur in case-marked argument positions and does not require adjacency. In contrast, the belong-to relation is not established in the grammar unless the singular kind term undergoes PI, and PI has positional and case-related restrictions. Outside of PI, singular kind terms can only receive a representative object reading when they occur in object-level contexts, as discussed in Sect. 4.2. In addition, DKP differs from PI in not being subject to the name-worthiness condition. We will explore these difference further in Sect. 6.

In sum, we have seen how PI with singular kind terms is possible. In the following section, I show that subjects can also be PI-ed in Turkish, which will prove to be in line with my analysis of bare singulars and PI.

\subsubsection{Subject pseudo-incorporation}

I have argued that PI occurs with singular kind terms in Turkish. I have also argued that bare singulars in case-marked argument positions, as opposed to those participating in PI, are singular definites. A striking confirmation of these claims comes from examples such as (59), where a bare singular subject immediately precedes the verb and yields a number neutral reading:
Ali-yi arı sok-tu.
Ali-ACC bee sting-PAST
'Ali got bee-stung.' (one or more bees)

Although PI usually targets direct objects, it has been noted in the literature that PI of subjects is possible under certain conditions. Farkas and de Swart (2003), for example, discuss subject PI in Hungarian, and Öztürk (2005, 2009) specifically argues for this for (59). ${ }^{36}$ She provides two pieces of evidence for the claim that subject PI is possible in Turkish, which I elaborate on within the terms of the present analysis. The first one comes from the contrast between (59) and (60) (Öztürk 2005, p. 42). As noted earlier, an adjacency relation holds between the bare singular and the incorporating verb. When that is not in evidence, the bare singular subject cannot be PI-ed, and hence undergoes iota type-shifting to yield a definite singular reading. In other words, the bare singular arl 'bee' is too far from the verb to allow PI in (60).

\footnotetext{
36 In Turkish, all types of nouns, animate or inanimate, are perfect candidates for PI with unaccusative verbs. With transitive and unergative verbs, human-denoting bare singulars can only be PI-ed in evidential contexts, where the identity of the subject feels less important, e.g., Bu resmi çocuk çizmiş. 'This picture is child-drawn.'
} 
(60) Arı Ali-yi sok-tu.

bee Ali-ACC sting-PAST

'The bee stung Ali.' (undefined if more than one bee stung Ali)

The second piece of evidence comes from the case-assignment facts. Öztürk (2005) claims that canonical subjects bear the null nominative case, being introduced in the functional domain, whereas PI-ed subjects receive no case because they are introduced VP internally. The difference in case is visible in embedded nominalized clauses in which canonical subjects receive the genitive case marking, as in (61a), whereas PI-ed subjects remain non-case-marked, as in (61b) (Johanson 1977; Kornfilt 1984, 1997, 2009; von Heusinger and Kornfilt 2005).
a. Arı*(-nın) Ali-yi sok-tuğ-un-u
bil-iyor-um.
bee-GEN Ali-ACC sting-NMLZ-3SGPOSS-ACC know-PROG-1SG
'I know that the bee stung Ali.' (canonical subject)
b. Ali-yi arı(-nın) sok-tuğ-un-u
bil-iyor-um.
Ali-ACC bee-GEN sting-NMLZ-3SGPOSS-ACC know-PROG-1SG
without GEN: 'I know that Ali got bee-stung.' (PI)
with GEN: 'I know that the bee stung Ali.' (canonical subject)

To Öztürk's arguments, I add evidence from modification. As (62) shows, it is possible to have European bee-stinging, but not broken-wing bee-stinging. This is compatible with the claim that PI-ed bare singulars do not take object-level modifications but rather take taxonomic-level modifications. (The adjective siyah 'black' in (62b) defines the European honey bee.)
a. *Ali-yi kırı kanat-lı arı sok-tu.
Ali-ACC broken wing-with bee sting-PAST
Intended: 'Ali got broken-wing bee-stung.'
Good: 'The bee with broken wings stung Ali.'
b. Ali-yi siyah arı sok-tu.
Ali-ACC black bee sting-PAST
'Ali got European bee-stung.'

I thus propose that bare singulars as in (59) also fall into the same analysis as object PI:

VI. Non-case-marked bare singular subjects are instances of subject PI in Turkish and the apparent number neutrality is due to their incorporation as singular kind terms.

To reiterate, as in object PI, PI-ed subjects are introduced inside the VP. This not only results in their inability to bear case, but also explains their adjacency to the verb. Since case-marked arguments are situated outside the VP, they linearly precede the VP internal PI-ed subject. This is why, when an accusative case-marked argument intervenes between a subject and a verb as in (60), the subject cannot be a PI-ed subject. In other words, a caseless argument cannot precede a case-marked argument due to its position in the structure. 
Semantically, then, PI-ed subjects are also singular kind terms incorporating to the verb to yield sub-event types. This time the Inc function takes the agent function $\mathrm{Ag}$ of type $\langle\langle v, t\rangle,\langle e,\langle v, t\rangle\rangle\rangle$ and turns it into an incorporating agent function, $A g_{I N C}$ of type $\left\langle\langle v, t\rangle,\left\langle e^{K},\langle v, t\rangle\right\rangle\right\rangle$. Similar to $T h_{I N C}, A g_{I N C}$ takes a verb and a singular kind term to denote a predicate of events whose agent belongs to the referent of the singular kind term, as shown in (63). ${ }^{37}$ Based on this, the syntax and semantics of (59) are illustrated in (64), ignoring tense again. It means that Ali is involved in a bee-stinging event type as a theme. A bee-stinging event type is a stinging event with an agent that belongs to the bee kind. Since the members of a kind can be both atomic (a bee) and plural individuals (bees), PI yields a number neutral interpretation.

$$
\begin{aligned}
& \llbracket A g_{I N C} \rrbracket=\lambda V_{\langle v, t\rangle} \lambda x^{K} \lambda e . \exists y\left[\text { belong-to }\left(y, x^{K}\right) \wedge V(e) \wedge A g(e)=y\right] \\
& \text { a. }\left[{ }_{v P}[D P A l i . A C C]\left[v^{\prime}[V P[P I-N P \text { bee }][V[\operatorname{AgINC} \operatorname{Inc} A g][V \text { sting }]]] v_{T h}\right]\right] \\
& \text { b. } \exists e \exists y[\text { belong-to }(y, \iota X[B E E(X)]) \wedge \operatorname{sting}(e) \wedge A g(e)=y \wedge T h(e)=A l i]
\end{aligned}
$$

In contrast, in (60), both the subject and the object are canonical arguments introduced at the functional domain and receive case. Semantically, the bare singular arl 'bee' denotes an ordinary atomic property which undergoes iota type-shifting to denote a contextually salient unique bee individual, and becomes an agent argument of the event via the canonical $A g$ function.

Recall that PI-ed bare singulars obligatorily take scope under other quantifiers. Accordingly, if (59) is negated, we get the expected $\neg>\exists$ reading: Ali did not get bee-stung (no bees involved). As in object PI, this is because the agent of the event is introduced through $\exists$-quantification over the individuals that have a belong-to relation with the kind as part of the event meaning. Since the event quantifier always takes narrow scope with respect to other quantificational elements, this $\exists$-quantification is also interpreted under these quantificational elements.

To conclude, subject PI is also possible in Turkish and when we have a PI-ed singular subject, we have number neutrality.

\subsection{The existential copular construction and pseudo-incorporation}

I now turn to the existential copular construction, which is another instance where bare singulars are interpreted number neutrally, as repeated below. I argue that the number neutrality of bare singulars in this position is also due to subject PI.

Oda-da fare var.

room-LOC mouse exist

'There are one or more mice in the room.'

\footnotetext{
37 Notice also that the PI of indirect objects is not as common as direct objects, though possible. When they PI, they are not case-marked, e.g., çocuk bakmak 'to do baby-sitting'; çocuk receives dative case in the nonPI-ed version. However, if the case marking expresses a location then it is still preserved in PI, e.g., doktor-a çıkmak 'to go to the doctor' (Jo and Palaz 2019a, b). These are still instances of PI since the goal/location bears the signature properties, number neutrality, narrow scope interpretations, and the compatibility with only taxonomic modification. How case-marking is retained in the latter needs explanation, but we could say that $I n c$ also applies to the goal function.
} 
In the existential copular construction, a locative phrase is followed by a pivot, which in turn is followed by the existential copula var. The pivot is a bare singular in (65) but bare plurals, indefinites, numerical and universally quantified expressions, definites, demonstratives, pronouns, and proper names can also be pivots, as shown in (66). Unlike existential clauses in other languages, Turkish existential clauses are unrestricted in that respect and do not show a definiteness effect (cf. Kelepir 2001).

(66) a. İçeride fareler/bir fare/iki fare var.

'There are mice/is a mouse/are two mice inside.

b. İçeride her fare/fare/fareler/o fare/o/Mickey Mouse var.

Literally: 'There is every mouse/the mouse/the mice/that mouse/(s)he/Mickey Mouse inside.'

There is an adjacency relation between the pivot and the existential copula, as evidenced by the fact that the sentence becomes ungrammatical if the pivot is leftdislocated (Taylan 1984). However, as is the case with PI, the separation of the pivot from the existential copula can be successful for discourse-related reasons such as contrastive topicalization.

The semantics of existential clauses has been well studied cross-linguistically, and various theories have been put forward for their interpretation (e.g., Milsark 1974; Barwise and Cooper 1981; Keenan 1987; Landman 2004; McNally 1992; Francez 2007). Among them, Milsark (1974) proposes that the existential predicate contributes an $\exists$-quantifier and the pivot serves as its restrictor, denoting a property. Under this analysis, we would expect bare singulars in the existential copular construction to denote properties, and the construction to yield a definiteness effect. But we have seen that the definiteness effect does not hold in Turkish.

Furthermore, it would be misleading to treat bare singulars as properties in this construction for the following reason. As discussed in Sect. 2, a bare singular in the existential copular construction, when modified, yields a contrast with respect to the type of modification. Like in the case of PI, bare singulars cannot receive object-level modification when they convey a number neutral reading. This type of modification is only possible if they are interpreted as singular definites, as shown in (67b). However, with adjectives that can have a taxonomic meaning, the definite interpretation is not obligatory, as shown in (67a).

a. Kutu-da dinil bilimsel kitap var.

box-LOC religious scientific book exist

'This box has the religious/scientific book.'

'There are one or more religious/scientific books in this box.'

b. Kutu-da eskil küçük kitap var.

box-LOC old small book exist

'This box has the old/small book.' (undefined if more than one old/small book)

These facts show that bare singulars cannot serve as the property denoting restrictor to the $\exists$-quantifier presumably introduced by the copula and yield a standard indefinite reading. Therefore, I propose the following: 
VII. Bare singulars in the existential copular construction can be a singular definite at the ordinary object level or a singular kind term. In the latter case, they undergo subject PI, and hence yield number neutrality due to the association of singular kinds with their members through the belong-to relation established as part of PI semantics.

More precisely, I claim that in the existential clauses of Turkish, the copula var denotes a property of existing/being present and the pivot is a subject bearing the theme role on par with unaccusative constructions. This explains the unrestricted nature of the pivot in Turkish, as opposed to languages like English. The locative phrase, on the other hand, is an argument that specifies the contextually salient location or time of existence/presence. ${ }^{38}$ Crucially, when a singular kind term is the pivot, differently from the other pivots, subject PI occurs. Namely, singular kind terms are introduced by the incorporating $T h_{I N C}$ function to yield a sub-type of the existence event/state. The PI-ed singular kind term refers to the kind that the theme argument of this event/state belongs to. This in turn ensures number neutrality as in canonical cases of PI. The syntax and semantics of (65) are given below. I call the functional head introducing the locative argument as little $v$-locative and represent it as $\mathrm{v}_{\text {Loc }}$ for consistency. ${ }^{39}$

$$
\begin{gathered}
\text { a. }\left[v P[P P \text { room.LOC }]\left[v^{\prime}[V P[P I-N P \text { mouse }][v[\operatorname{ThINC} \text { Inc Th }][v \text { var }]]] v_{\text {Loc }}\right]\right] \\
\text { b. } \llbracket 65 \rrbracket=\exists e \exists y[\text { belong-to }(y, \iota X[M O U S E(X)]) \wedge \operatorname{exist}(e) \wedge T h(e)=y \\
\wedge \operatorname{Loc}(e)=\iota x[\operatorname{room}(x)]]
\end{gathered}
$$

Similar to the case discussed in Sect. 5.1.3, all pivots except for singular kind terms receive the null nominative case marker, and this difference becomes visible in nominalized embedded clauses, where the nominative case is replaced by the genitive case marking: ${ }^{40}$

\footnotetext{
38 The existential copular construction receives a possessive meaning when the locative phrase is animate like a human, e.g., Bende bu kitap/kitap var. 'I have this book/one or more books.' This is expected since the interpretation of the copula is being present at a location, applying to this case as being present at one's possession. Notice that the regular possessive construction also makes use of the copula var, as in Ben-im kitab-ım var. 'I have one or more books.' This differs from the one analyzed here in that the possessor bears the genitive case (-im above), rather than the locative marker, and the possessee bears the possessive person agreement marker (-Im above). The facts of modification also hold for this case, so it could be considered under a similar analysis. See Kelepir (2001) for the types of the existential copular construction, and Öztürk and Taylan (2016) for possessive structures.

39 Espinal and McNally (2011) treat bare singulars occurring in Spanish and Catalan existential clauses as PI.

40 The existential copula var is realized as the copula ol- in embedded structures (Göksel 2003; Kelepir 2003). Notice also that the existential copular construction requires an adjacency relation between all types of pivots and the copula, not just the PI-ed pivot and the copula, for some reason that is unclear at the moment. This is not the case with regular unaccusative constructions. We could assume that just like noncase-marked direct objects, all pivots are introduced VP internally instead of in the higher case assigning domain. This would explain the adjacency for the elements introduced inside the VP are more restricted in terms of the degree of syntactic freedom. However, this would leave the facts of case marking unexplained because VP internal arguments, both objects and subjects, as shown in the analysis of PI, do not receive case (cf. Kelepir 2001). In the existential copular construction, it is syntactically evident that all pivots except for singular kind terms receive the null nominative case, as shown in (69). This aligns with the facts of subject PI.
} 
a. Bu oda-da Ali*(-nin) ol-duğ-un-u bil-iyor-um. this room-LOC Ali-GEN be-NMLZ-3SGPOSS-ACC know-PROG-1SG Literally: 'I know that there is Ali in this room.' (canonical pivot)

b. Bu oda-da fare(-nin) ol-duğ-un-u bil-iyor-um. this room-LOC mouse-GEN be-NMLZ-3SGPOSS-ACC know-PROG-1SG without GEN: 'I know that there are one or more mice in this room.' (PI) with GEN: 'I know that this room has the mouse.' (canonical pivot)

With this analysis, we expect bare singulars in the existential copular construction to convey narrow scope readings due to PI as opposed to other pivots. ${ }^{41}$ For example, in (70), the event quantification takes narrow scope with respect to the universal quantification, which also results in a narrow scope interpretation for the PI-ed singular kind term.

$$
\begin{aligned}
& \text { Ev-in her yer-in-de fare var. } \\
& \text { house-GEN every place-3SGPOSS-LOC mouse exist } \\
& \text { 'Everywhere in the house there are one or more mice.' } \\
& \forall z[\text { place.of.house }(z) \rightarrow \exists e \exists y[\text { belong-to }(y, \iota X[\operatorname{MOUSE}(X)]) \wedge \operatorname{exist}(e) \\
& \wedge T h(e)=y \wedge \operatorname{Loc}(e)=z]]
\end{aligned}
$$

In sum, we have ample evidence that the number neutrality of bare singulars in the existential copular construction follows from their incorporation as singular kind terms.

\subsection{Singular kind reference in the predicate position}

Finally, let us consider the number neutrality of bare singulars in the predicate position. Analogous to the analysis of PI, I claim that bare singulars in the predicate position can have singular kind reference and that the apparent neutrality follows from that.

Recall the challenge posed by bare singulars in the predicate position: Given our claim that bare singulars in Turkish denote atomic properties, we expect them to be predicated of singular subject terms only. However, they can be predicated of plural subjects, too. The relevant example is repeated below as (71).

Ali ve Merve çocuk.

Ali and Merve child

'Ali and Merve are children.'

As shown in Sect. 2, this use of bare singulars is restricted in terms of what kind of modification they may receive. We have established above that the denotation of bare singulars can be ascertained on the basis of taxonomic-level vs. object-level modification. This diagnostic also applies to the case under discussion. When bare singulars in the predicate position receive taxonomic modification, the predication is compatible with singular and plural subjects. In contrast, when they receive object-level modification, the predication is only compatible with singular subjects, as repeated below.

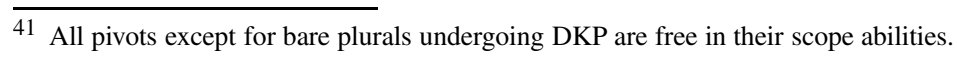


a. Ali (ve Mehmet) pratisyen doktor.

Ali and Mehmet practitioner doctor

'Ali is a practitioner doctor./Ali and Mehmet are practitioner doctors.'

b. Ali (*ve Mehmet) yakışıll doktor.

Ali and Mehmet handsome doctor

'Ali is a handsome doctor.' Not: 'Ali and Mehmet are handsome doctors.'

The latter case is predicted by the claim that bare singulars denote atomic properties of ordinary individuals (i.e., Claim I), which receive object-level modification. Additionally, since they are atomic properties, they can only be predicated of singular subjects. ${ }^{42}$ In parallel with PI, the former case is explained by the last core claim of my account of Turkish bare singulars: ${ }^{43}$

VIII. Bare singulars can appear as singular kind terms in the predicate position, being only compatible with taxonomic modifiers. Number neutrality is ensured because, just as in PI, the predicate position makes it possible for the conceptual belong-to relation to be established in the grammatical component.

More precisely, the copula plays the role of a null operator. It takes a singular kind term as predicate and a subject term (singular or plural), and establishes the belong-to relation between the referents of the two. ${ }^{44}$ I will call this phenomenon kind specification where a kind that the referent of the subject term belongs to is specified. The denotation that the copula has in this construction is given in (73a), and the logical form of the sentence Ali çocuk. 'Ali is a child.' is shown in (73b).

$$
\begin{aligned}
& \text { a. } \llbracket \mathrm{COP} \rrbracket=\lambda x^{K} \lambda y . \text { belong-to }\left(y, x^{K}\right) \\
& \text { b. } \llbracket \text { Ali child } \rrbracket=\text { belong-to }(\text { Ali }, \iota X[C H I L D(X)])
\end{aligned}
$$

Kind specification can also be achieved if the subject is a plural term, considering that sum individuals are also members of kinds. This explains the compatibility of bare singulars with plural subjects in the predicate position. The logical form of (71) is given below. ${ }^{45}$

$$
\llbracket \text { Ali and Merve child } \rrbracket=\text { belong-to }(\text { Ali } \oplus \text { Merve, } \iota X[C H I L D(X)])
$$

\footnotetext{
42 Bare singulars in the predicate position resist modification by complex structures like relative clauses and postpositional phrases, either being interpreted as definite or requiring the indefinite form. This paper does not offer an explanation for this restriction. The main purpose is to show that modification of bare singulars when available yields interesting predictions regarding the number interpretation.

43 Bare singulars in the predicate position can also be found in Romance and Germanic languages like Dutch, French, Spanish, and German, although their usage is more restricted compared to the ones in Turkish. See de Swart et al. (2007) for an account of them which is along the same lines as the analysis given here.

44 It has been claimed that there is a null copula in the predicate position, and that it is the present tense realization of the copula $-i$, which is overtly realized with other tenses (Kornfilt 1996; Kelepir 2003).

45 One could argue that the ability of a bare singular to occur with a plural subject is due to a null Distributive operator that takes an atomic property denoted by a bare singular and distributes it over the atomic parts of a plural subject. However, a solution of this type cannot be adopted since in that case, bare singulars modified at the ordinary object level would also be predicated of plural subjects. This is not the case, as shown in (72b).
} 
To summarize, I have shown in Sect. 5 how the three cases where bare singulars have number neutral interpretations can be derived in a principled manner while maintaining their semantically singular status. I have argued that bare singulars are ambiguous between atomic properties of object-level and taxonomic entities, which, via covert $\iota$ type-shifting, become either a singular definite or a singular kind term. I have attributed their number neutral interpretation to their singular kind reference.

\section{Further issues and predictions}

In this final section I take up two issues that remain to be addressed. The first concerns the status of case-marked vs. PI-ed singular kind terms. The second issue has to do with the status of bare plurals in the non-case-marked direct object and predicate positions.

\subsection{Remarks on case-marked versus pseudo-incorporated singular kind terms}

So far we have discussed variations in interpretation between PI-ed singular kind terms and case-marked bare singulars denoting at the ordinary object level. But the proposal I have made to capture the variations between them makes some further predictions about the differences between PI-ed singular kind terms and cased-marked bare singulars that are also singular kind terms. This section will show that those predictions are borne out.

Consider the following statements that are clearly about the computer kind. In (75a), we have the predicate invent that requires a kind term as its argument. In (75b), we have a singular kind term, too, but the truth of the statement involves some particular computers. That is, the kind term has a representative object reading.

a. Charles Babbage bilgisayar-1 icat et-ti.

Charles Babbage computer-ACC invent-PAST

'Charles Babbage invented the computer.'

b. Bu ülke bilgisayar-a çok geç kavuş-tu. this country computer-DAT very late have-PAST

'This country had (obtained) the computer very late.'

A question that arises is what the difference between a representative object reading and a PI reading of a singular kind term might be. Both involve, at the intuitive level, the predicate to hold of object-level members of the species, but there are some clear markers separating the two. The representative object reading, but not the PI reading, carries the sense that the statement is significant for the kind as a whole. To see this in concrete terms, let us compare (76) with and without the accusative case marker on the singular kind term ayl 'the bear':

(76) Sonunda bu hayvanat bahçesi-ne ayı(-yı) getir-di-ler. finally this zoo-DAT bear-ACC bring-PAST-3PL 
with ACC: 'Finally, they brought the bear (kind) to this zoo.'

without ACC: 'Finally, they did bear-bringing/delivery to this zoo.'

a. with ACC: $\exists e[$ bring.to.zoo $(e) \wedge T h(e)=\iota X[B E A R(X)] \wedge A g(e)$

$$
=\text { they] }
$$

b. without ACC: $\exists e \exists y[$ belong-to $(y, \iota X[B E A R(X)]) \wedge$ bring.to.zoo $(e) \wedge$

$$
T h(e)=y \wedge A g(e)=\text { they] }
$$

In (76), ayı is a canonical direct object if it is accusative case-marked, as shown in (76a). It requires for its felicitous use that prior to the delivery, the zoo not have any bears. In other words, being brought to this zoo is momentous for the bear kind, and hence the bare singular has a representative object reading. The PI-ed version, without the case marker, does not impose a similar requirement. All that is required for the adverb 'finally' to be used felicitously in this case is that there has been a plan for some time to bring (more) bears to the zoo. As shown in (76b), the theme of the event is an object-level entity or entities in the belong-to relation to the bear kind, and what is at issue is what type of a bringing event has taken place, i.e., bear-bringing/delivery. In short, while in (76a), the protagonist of the event is the bear kind, in (76b) it is a member or some members of the bear kind, the identity of which is not relevant.

This subtle but robust difference also shows up in a variant of (76) in which there is a universal quantifier in the subject position. We expect that the narrow scope interpretation of the singular kind term is only possible if it is PI-ed:

Sonunda her kurum bu hayvanat bahçesi-ne ayı(\#-yı) getir-di. finally every foundation this zoo-DAT bear-ACC bring-PAST with ACC: 'Finally, every foundation brought the bear (kind) to this zoo.' without ACC: 'Finally, every foundation did bear-bringing/delivery to this zoo.'

a. with ACC: $\forall x$ [foundation $(x) \rightarrow \exists e[$ bring.to.zoo $(e) \wedge T h(e)$ $=\iota X[B E A R(X)] \wedge A g(e)=x]]$

b. without ACC: $\forall x[$ foundation $(x) \rightarrow \exists e \exists y[$ belong-to $(y, \iota X[B E A R(X)])$ $\wedge$ bring.to.zoo $(e) \wedge T h(e)=y \wedge \operatorname{Ag}(e)=x]]$

Imagine a context where there are a few foundations responsible for bringing animals to zoos. The accusative case-marked version, represented in (77a), receives the implausible reading that each foundation brought the bear kind to the zoo. In this case, the bear/bears brought to this zoo stand for the whole bear kind as a unique singleton/group individual, ensuring a total reference to the kind. Since definites are scopally inert, the singular kind term cannot take scope under the quantifier, resulting in infelicity. However, as expected, it can describe a situation as follows: First, a group of bears representing the bear kind is brought to the zoo, but for some reason the group is returned. Then, another foundation brings what is probably a different group, but this group is also returned. This continues until each foundation happens to bring the bear kind to the zoo. Crucially, it does not describe a situation where each foundation brings a different part of the same representative group.

In contrast, the PI-ed version is interpreted as distinct bear-bringing events for each foundation. This is ensured by the event quantifier taking narrow scope with respect to the universal quantifier. Since the belong-to relation is established through an $\exists$-quantification as part of the event meaning, we get the reading in (77b). 
To complete the picture, recall from Sect. 4.2 that singular kind terms in case-marked argument positions are incompatible with distributive predicates. We can compare this to a minimal variant in which the the kind term is not case-marked:
a. *Ayı bu hayvanat bahçesi-ne farklı bölge-ler-den gel-di. bear this zoo-DAT different region-PL-ABL come-PAST Intended: 'Bears came to this zoo from different regions.'
b. Kurum bu hayvanat bahçesi-ne farklı bölge-ler-den ayı foundation this zoo-DAT different region-PL-ABL bear getir-di. bring-PAST
'The foundation did bear-delivery to this zoo from different regions.'

The unacceptability of (78a) follows from the fact that the singular kind term does not provide access to object-level bears for distributivity to work on. The PI-ed version in (78b), on the other hand, is grammatical because from different regions modifies the event of bear-bringing/delivery, not the singular kind. In other words, (78b) refers to distinct events of bear-bringing/delivery, each of which is done from a different region, and each bear-bringing event involves different members of the bear kind as its theme. ${ }^{46}$

In sum, we have compared PI-ed and case-marked singular kind terms and seen that the present analysis correctly predicts the variations between the two.

\subsection{The competition between singular and plural kind reference}

I have explained the number neutrality of Turkish bare singulars that are non-casemarked as a result of PI of a kind-denoting argument into a verb. I have also argued that Turkish bare plurals are kind denoting terms. A question that remains to be addressed, then, is the status of non-case-marked bare plurals. In other pseudo-incorporating languages with a singular-plural distinction in the nominal, such as Hindi and Hungarian, plural nouns are also claimed to undergo PI (Dayal 2011, 2015; Farkas and de Swart 2003). Based on this, one would expect Turkish bare plurals to participate in PI as well. However, this turns out not to be the case.

Consider, for example, the modification of the noun kitap 'book' by the object-level adjective eski 'old (worn-out)', which we noted to be unacceptable in the singular. The non-case-marked bare plural turns out to be fully acceptable:

Ali eski kitap-lar oku-du.

Ali old book-PL read-PAST

'Ali read old books.'

This shows at the very least that a bare plural can be interpreted non-specifically in the non-case-marked argument position. That is, we have the following possibilities in Turkish, where the VP internal position not only admits PI of bare singulars, but also DKP of bare plurals:

\footnotetext{
46 Subject PI would also be possible as the following: Bu hayvanat bahçesine farklı bölgelerden ayı geldi. 'Bear-coming happened to this zoo from different regions.'
} 

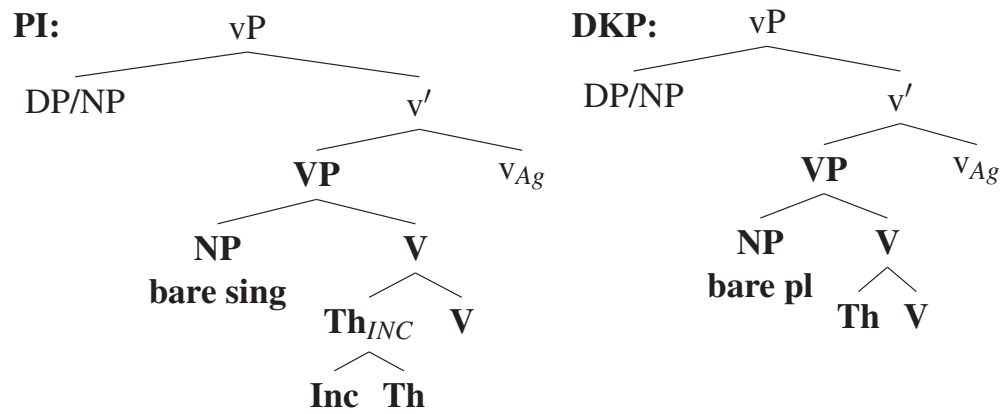

The bare plural in (79) is interpreted VP-internally without invoking PI. It functions as a canonical argument undergoing DKP, and is hence interpreted as a narrow scope existential, as shown in (81). Plural kind terms are derived from properties of ordinary objects, so the bare plural kitaplar 'books' is first modified with eski 'old' and then nom applies to the property of old books to denote its individual correlate, i.e., $\cap$ oldbook. When this kind individual combines with the object-level verb oku 'read', DKP applies, drawing on pred. Unlike PI, DKP is not conditioned by name-worthiness, and hence reading old books is acceptable.

$$
\llbracket 79 \rrbracket=\exists e \exists y[\operatorname{read}(e) \wedge \cup \cap \operatorname{old}-\operatorname{book}(y) \wedge T h(e)=y \wedge A g(e)=A l i]
$$

The question we must answer is whether the bare plural can also participate in the PI structure given in (80). To put it differently, the question is whether the incorporating thematic functions can also apply to plural kind terms, forming an instantiation-of relation, similar to DKP. I claim that bare plurals cannot be PI-ed and that a competition occurs between singular and plural kind terms in the VP-internal position, with the former being privileged and blocking the other. The empirical basis for this claim comes from the plural version of a simple PI example:

\section{*Ali kitap-lar oku-du. \\ Ali book-PL read-PAST \\ Intended: 'Ali did book-reading.'}

The sentence in (82) is awkward at best, and is ungrammatical if it is intended to convey a sub-event type reading. It becomes acceptable if the plurality is emphasized in a contrastive way (e.g., Ali kitap okumadl, KITAPLAR okudu. 'It is not the case that Ali read one or more books, Ali read BOOKS.'), or when abundance in number is emphasized. ${ }^{47}$ Crucially, though, when PI is not possible as in the case of ordinary object-level modification, bare plurals are good in this position without contrastiveness or emphasis on the plurality, as shown in (79) above.

To reiterate, when PI of a bare singular is possible in the non-case-marked direct object position, bare plurals are ruled out unless used independently for emphasizing/contrasting the plurality. However, when PI is infelicitous, bare plurals surface in this position without a need for a marked interpretation. This not only shows that bare

\footnotetext{
47 See also Ketrez (2004) for the multiple events reading that is available in certain conditions, e.g., doing book-reading multiple times. Such readings are not always available and they add a flavor of exaggeration.
} 
plurals do not participate in PI but also that PI has a blocking effect over non-casemarked bare plurals undergoing DKP.

I suggest that PI blocks DKP because the belong-to relation applying to singular kind terms has a privileged status over the instantiation-of relation applying to plural kind terms via pred. The rule in (83) ensures that PI will apply over DKP, letting DKP apply only when PI is not available in the same syntactic position, or when needed independently for contrastive and abundance interpretations.

When the belong-to relation and pred are both available in the same syntactic position, apply the belong-to relation.

Note that in case-marked argument positions, whether they undergo DKP or iota typeshifting, plurals are perfectly fine without a marked reading. This is because PI is not available in the functional domain outside of VP. More precisely, DKP of bare plurals is restricted in the non-case-marked direct object position only, i.e., when it occupies the same position with PI.

These effects are most visible in the subject position. Recall that Turkish allows PI of bare singulars in the subject position, as repeated in (84a). As predicted, the plural version of (84a) with art-lar is unacceptable with the intended PI meaning of beestinging. It can only occur as a canonical argument with nominative case that receives an existential reading via DKP or a definite reading via iota. This is evidenced by the obligation of plurals to receive the genitive case in nominalized embedded clauses, as shown in (84b) (cf. with (61b)).
a. Ali-yi arı(-lar) sok-tu.
Ali-ACC bee-PL sting-PAST
without PL: 'Ali got bee-stung.' (one or more bees)
with PL: 'Ali got stung by (the) bees.' (more than one bee)
b. Ali-yi arı-lar*(-In) sok-tuğ-un-u bil-iyor-um.
Ali-ACC bee-PL-GEN sting-NMLZ-3SGPOSS-ACC know-PROG-1SG
'I know that (the) bees stung Ali.' (more than one bee)

The bare plural does not compete with the PI-ed singular kind term when it receives a DKP-derived interpretation in these examples. This is because the bare plural and the PI-ed singular kind term do not occupy the same syntactic domain in the subject position. While the PI-ed bare singular is still in the caseless VP internal domain, the bare plural occupies the functional domain this time, receiving case. So bare plural subjects are still good in the preverbal position without the restrictions observed in their object counterparts. ${ }^{48}$

The fact that bare plurals can occur in the non-case-marked direct object position adjacent to the verb as PI-ed bare singulars, does not mean that they are instances of the same phenomenon. ${ }^{49}$ A good way of supporting this idea would be to find contrasts

\footnotetext{
48 These facts also hold in the existential copular construction. This is predicted since PI manifests itself as subject PI in this construction, and bare plural pivots are canonical case receiving arguments.

49 The caseless direct object position can only be occupied by non-specific objects. Specific and definite direct objects obligatorily receive accusative case in episodic contexts (Enç 1991), but non-specificity can still be achieved with other case markers. Bare plural direct objects are interpreted as definites when
} 
between PI of singular kind terms and DKP of plural kind terms, especially in terms of the hallmarks of PI, name-worthiness, number neutrality, and obligatory narrow scope. Unfortunately, the narrow scope property does not differentiate between the two since it is ensured for bare plurals by DKP anyway. Name-worthiness and number neutrality might be considered as distinctive properties, however. As we have seen above, noncase-marked bare plurals are not subject to name-worthiness and hence are compatible with modifiers that PI-ed bare singulars are not. Furthermore, as shown in Sect. 3.2, bare plurals in Turkish are number neutral, though they receive an exclusive reading in positive contexts due to a conversational implicature. So, (79) has a strict plural reading. In contrast, a number neutral interpretation is always inferred from a PI-ed bare singular and does not involve a conversational implicature. These contrasts show that DKP and PI are distinct phenomena. ${ }^{50}$

Another contrast that proves helpful on this point is the occurrence of PI with non-derived adverbs in Turkish. Taylan (1984) shows that non-derived adverbs, i.e., adjectives that act like adverbs, always have to occupy an immediate pre-verbal position and cannot precede a case-marked argument, as in (85). However, in the case of PI, they have to precede the PI-ed bare singular, as shown in (86) (Öztürk 2005; Aydemir 2004; Kamali 2015).

a. *Ali yavaş kitab-1 oku-du.

*[Subj [Adv [Obj.ACC V]]]

Ali slow book-ACC read-PAST

'Ali read the book slowly.'

b. Ali kitab-1 yavaş oku-du.

[Subj [Obj.ACC [Adv V]]]

Ali book-ACC slow read-PAST

'Ali read the book slowly.'

a. Ali yavas kitap oku-du.

[Subj [Adv [PI.Obj V]]]

Ali slow book read-PAST

'Ali did book-reading slowly.'

b. *Ali kitap yavaş oku-du.

Ali book slow read-PAST

'Ali did book-reading slowly.'

*[Subj [PI.Obj [Adv V]]]

Non-case-marked bare plurals pattern with case-marked arguments in that they cannot be preceded by non-derived adverbs, as shown in (87). Instead, as in (88a), these modifiers modify the bare plural rather than the verb (Aydemir 2004). Notice that if the sentence has a bare singular, as in (88b), güzel 'nice' still acts as a non-derived adverb. If the modifier is intended to be used as an adjective, it requires the indefinite form, since it is an ordinary object-level modifier. As we have seen above, such modifiers are incompatible with PI-ed bare singulars.

Footnote 49 continued

accusative case-marked, and as narrow scope existentials when non-case-marked. With other case markers, they get both readings. However, the accusative case does not necessitate specificity/definiteness in generic contexts.

50 In addition, non-case-marked bare plural objects introduce discourse referents, as opposed to PI-ed bare singulars for which this is a trickier issue (see Aydemir 2004; Kamali 2015). See fn (18). 
(87) *Ali yavaş (eski) kitap-lar oku-du.

*[Subj [Adv [DKP.Obj V]]]

Ali slow old book-PL read-PAST

'Ali read (old) books slowly.'

a. Ali güzel kitap-lar oku-du.

[Subj [Adj [DKP.Obj V]]]

Ali nice book-PL read-PAST

'Ali read nice books.'

b. Ali güzel kitap oku-du.

Ali nice book read-PAST

[Subj [Adv [PI.Obj V]]]

'Ali did book-reading nicely.'

It seems that in the case of PI, non-derived adverbs modify the event after the subevent type is formed and before canonical arguments are introduced. It is plausible to consider them to have a restrictive function on the (sub-)event type. Based on this approach, the book-reading event type modified by the adverb yavaş 'slowly' in (86) is a sub-type of book-reading events: slow book-reading (vs. fast book-reading). Since the modification happens as part of the sub-event type, it is expected to occur before canonical arguments are introduced. This might explain why non-derived adverbs cannot precede canonical arguments. Given that they cannot precede bare plurals, either, it is reasonable to conclude that non-case-marked bare plurals have a distinct status from PI-ed bare singulars. ${ }^{51}$

Besides bare plurals, numerical expressions and indefinites formed with the numeral bir 'one', i.e., weak indefinites, can also occur adjacent to the verb without receiving an overt case-marking, further supporting the idea that the non-case-marked direct object position is not only dedicated to PI. In this position, they are interpreted as non-specific, as opposed to specific indefinites with bazl 'some', universal quantifiers, pronouns, and definites, which always have to receive case. Kamali (2015) compares weak indefinites with PI and argues that the former cannot be analyzed as an instance of the latter (cf. Öztürk 2005). She shows that weak indefinite objects do not convey a number neutral reading and there are some cases where they yield wide scope readings. Aydemir (2004) also distinguishes them from PI, showing that non-derived adverbs cannot precede weak indefinite objects, as opposed to PI-ed bare singulars.

Obviously, being a non-case-marked direct object that requires some degree of adjacency to the verb is the reflection of a more general phenomenon related to nonspecificity, and PI of bare singulars is just an instance of it. To recap how these issues fit into my account, there are two things that need to be emphasized. First, strict adjacency between a PI-ed noun and a verb is not a property that Turkish exhibits. Second, fairly strict word order restrictions concerning PI-ed nouns are also shared by non-specific bare plural and indefinite direct objects. I understand these restrictions to be a result of these arguments being in the VP internal position. A robust syntactic reflex of this is their inability to bear case or undergo case-driven movement.

\footnotetext{
51 Non-derived adverbs cannot follow non-case-marked bare plurals, either. It is because the position of these adverbs is assumed to be the edge of VP and bare plurals undergoing DKP are in the complement position of the verb. If non-derived adverbs were ever compatible with non-case-marked bare plurals, they would be expected to precede them. However, as stated above, they cannot do so for semantic reasons.
} 
I will now show that, similar to PI, kind specification also blocks plural kind terms in the predicate position. We would expect bare plurals to appear in this position in two ways. One is to occur as properties, and the other is as definites, undergoing typeshifting via iota. However, the first option is unavailable, as evidenced by (89) which means 'Ali and Mehmet are the doctors.', not 'Ali and Mehmet are doctors.', receiving an equative interpretation. ${ }^{52}$

\section{Ali ve Mehmet doktor-lar. \\ 'Ali and Mehmet are the doctors.'}

This does not mean that bare plurals can only be definite in the predicate position, since they can also have a predicative denotation if they are modified, as in (90a). However, for this, they should receive ordinary object-level modification. With adjectives that can function as taxonomic modifiers, as in (90b), the bare plural has an equative reading, just like in (89). ${ }^{53}$

\section{a. Ali ve Mehmet yakışıklı doktor-lar. \\ 'Ali and Mehmet are (the) handsome doctors.' \\ b. Ali ve Mehmet pratisyen doktor-lar. \\ 'Ali and Mehmet are the practitioner doctors.'}

The restricted use of bare plurals in the predicate position is similar to the case of bare plurals occurring in the non-case-marked direct object position. That is, bare plurals are only allowed to occur as properties in the predicate position when singular kind terms cannot participate in kind specification. This could therefore also be derived by the constraint given in (83).

One way for bare plurals to have a property denotation is through their kind reference, i.e., by type-shifting via pred. Since the predicate position is one of the two places where the belong-to relation is established in the grammar, its application bleaches pred, by (83). In contrast, the occurrence of bare plurals as definites in the predicate position is freely available since they are the only means for this interpretation. However, why bare plurals cannot appear as properties independently of their kind reference in this position remains as an open question, since it is not obvious why a singular kind term would block a plural property underived from a plural kind term. Indeed, the predicative use of an indefinite form is not blocked by the singular kind term, so it stays as an alternative usage even when kind specification is still available.

To wrap up, analyzing bare singulars that yield a number neutral reading in the non-case-marked direct object and predicate positions as singular kind terms turns out

\footnotetext{
52 Here, I assume that the stress falls on the plural marker. It is also possible that the syllable before -lAr is stressed instead, in which case $-l A r$ is the optional 3rd person plural agreement marker that appears on the bare singular (Göksel and Kerslake 2005). The stress pattern follows from the fact that the null copula, the present tense realization of the copula $-i$, is between the noun and the person agreement marker. Being a clitic, the copula shifts the stress to the preceding syllable (e.g., Kornfilt 1996; Kelepir 2003). See fn (44).

53 As pointed out in fn (7), Bale et al.'s (2010) claim of bare plurals to be exclusive of atoms is based on the fact that they cannot be predicated of singular subjects. This can be considered to be a result of a competition with singular forms, as in English: When bare plurals are definites, it competes with the singular definite denoted by the singular form. Similarly, when bare plurals are predicates, they compete with atomic predicates, i.e., bare singulars and singular indefinites in the predicative use.
} 
to be helpful in explaining the asymmetry between bare singulars and bare plurals in these positions. With this analysis, the blocking effect of the former on the latter nicely demonstrates a connection with their kind-level characteristics. The crucial question, though, is why there is a competition between the instantiation-of relation conveyed by pred and the belong-to relation at all. Although the exact reason behind this competition is obscure at this point, we can safely conclude that in Turkish, plural kind terms systematically have an under-privileged status with respect to singular kind terms. ${ }^{54}$

Turkish, in this respect, differs from English where singular kind reference has a more limited use compared to plural kind reference. While English singular kind terms are mostly restricted to well-defined or biological kinds, in Turkish singular kind formation applies to almost all sorts of nouns. Furthermore, the effects of singular kind reference are revealed more substantially in Turkish than in English, extending to phenomena that pertain to pseudo-incorporation and kind specification in the predicate position. Although similar effects are observed in English with weak definites, these phenomena have a very limited application compared to their highly productive status in Turkish. It should also be noted that English bare plurals are not subject to similar restrictions when they occupy the direct object position undergoing DKP, or when they occur as plural properties in the predicate position. Therefore, the extensive use of singular kind terms in Turkish together with the asymmetry between the two forms of kind reference also results in Turkish bare plurals having a more restricted distribution than English bare plurals.

\section{Conclusion}

This paper has explored the semantics of bare singulars in Turkish which have singular readings in some cases and number neutral readings in other cases. We have seen that while in case-marked argument positions Turkish bare singulars are interpreted as strictly singular, they yield a number neutral interpretation in non-case-marked argument positions, the existential copular construction, and the predicate position. This dual nature of Turkish bare singulars separates them from English singular nouns which behave as singular terms in a more systematic way.

Previous accounts analyze Turkish bare singulars as denoting number neutral sets, inclusive of atoms and pluralities, and Turkish bare plurals as denoting strictly plural sets, exclusive of atoms (Bliss 2004; Bale et al. 2010; Görgülü 2012). I have pursued an alternative approach and argued that Turkish bare singulars are also semantically singular, denoting sets of atoms only, while bare plurals are number neutral terms.

I have shown that the seemingly number neutral interpretation of bare singulars is derived through singular kind reference, and discussed the kind-level characteristics of Turkish bare nouns, drawing a line between plural and singular kind reference in light of the claims made in Chierchia (1998) and Dayal (2004). I have followed Dayal (2004) in that singular kind terms differ from plural kind terms in having an impure

\footnotetext{
54 See Sağ (2019) for a more extensive discussion on the underprivileged status of plural kind reference in Turkish.
} 
atomic nature, but at the same time retaining a conceptual relation with the objectlevel entities we intuitively associate with them. I have further proposed that this relation, i.e., belong-to, is in fact represented in the grammar in the three problematic constructions in Turkish.

Of the three constructions under discussion, I have analyzed the first two as instances of pseudo-incorporation (cf. Öztürk 2005). I have further analyzed Turkish pseudoincorporation as involving a kind-denoting singular theme argument (cf. Dayal 2011, 2015; Aguilar-Guevara and Zwarts 2010). Number neutrality is ensured by virtue of the fact that object-level entities that belong-to singular kinds can be both atomic and plural entities. I have also analyzed the number neutrality of bare singulars in the predicate position as being the result of a phenomenon that I have called kind specification. Similar to pseudo-incorporation, a special copular semantics taps into the belong-to relation between the referent of a singular kind term and the referent of a singular or plural subject term.

My analysis aligns Turkish with English and many other languages where the correlation between morphological and semantic (un)markedness is manifested asymmetrically. This contrasts with the opposing view where Turkish is located among few known languages realizing this correlation in a parallel way. The claim that singular kind reference extends to pseudo-incorporation and kind specification in the predicate position accounts for the difference between Turkish and English singular nouns in terms of number neutrality. We have seen that singular kind reference has similar effects in English through weak definites in a limited way (cf. Aguilar-Guevara and Zwarts 2010), but its productive status in Turkish makes these effects more visible in Turkish than in English. We have also seen that this extensive use of singular kind reference in Turkish has a bleaching effect on plural kind reference, resulting in a privileged status for bare singulars over bare plurals in the non-case-marked argument and predicate positions. This asymmetry separates Turkish bare plurals from English bare plurals, which are not subject to similar restrictions and therefore have a wider application.

In conclusion, we have seen that (singular) kind reference has applications in more places than we have previously been aware of. This is not only important for explaining the challenges of the Turkish number marking system; it also contributes to our understanding of kind reference in general, as well as its cross-linguistic variations.

Acknowledgements This publication was supported by the Princeton University Library Open Access Fund. I am grateful for helpful suggestions and discussion to Veneeta Dayal, Gennaro Chierchia, Simon Charlow, and Mark Baker. I am also indebted to Ömer Demirok, Jess Law, and the audience at Sinn und Bedeutung 22 for their insightful comments. I would like to thank the handling editor Regine Eckardt and four anonymous reviewers as this paper has considerably benefited from their feedback. All errors are my own.

Open Access This article is licensed under a Creative Commons Attribution 4.0 International License, which permits use, sharing, adaptation, distribution and reproduction in any medium or format, as long as you give appropriate credit to the original author(s) and the source, provide a link to the Creative Commons licence, and indicate if changes were made. The images or other third party material in this article are included in the article's Creative Commons licence, unless indicated otherwise in a credit line to the material. If material is not included in the article's Creative Commons licence and your intended use is not permitted by statutory regulation or exceeds the permitted use, you will need to obtain permission directly from the copyright holder. To view a copy of this licence, visit http://creativecommons.org/licenses/by/4.0/. 


\section{References}

Aguilar-Guevara, A., \& Zwarts, J. (2010). Weak definites and reference to kinds. Semantics and Linguistic Theory (SALT), 20, 179-196.

Arslan-Kechriotis, Z. C. (2006). Case as an uninterpretable feature. Ph.D. thesis, Boğaziçi University.

Aydemir, Y. (2004). Are Turkish preverbal bare nouns syntactic arguments? Linguistic Inquiry, 35(3), 465474.

Baker, M. C. (1988). Incorporation: A theory of grammatical function changing. Chicago: University of Chicago Press.

Baker, M. C. (1996). The polysynthesis parameter. New York: Oxford University Press.

Baker, M. C., Aranovich, R., \& Golluscio, L. (2005). Two types of syntactic noun incorporation: Noun incorporation in Mapudungun and its typological implications. Language, 81, 138-176.

Bale, A., \& Khanjian, H. (2014). Syntactic complexity and competition: The singular-plural distinction in Western Armenian. Linguistic Inquiry, 45(1), 1-26.

Bale, A., Khanjian, H., \& Gagnon, M. (2010). Cross-linguistic representations of numerals and number marking. Semantics and Linguistic Theory (SALT), 20, 1-15.

Barker, C. (1992). Group terms in English: Representing groups as atoms. Journal of Semantics, 9(1), 69-93.

Barwise, J., \& Cooper, R. (1981). Generalized quantifiers and natural language. Linguistics and Philosophy, $4(2), 159-219$.

Bittner, M. (1994). Case, scope and binding. Dordrecht: Springer.

Bliss, H. (2004). The semantics of the bare noun in Turkish. Calgary Working Papers in Linguistics, 25(Spring), 1-65. https://doi.org/10.11575/PRISM/28976.

Bosch, P., \& Cieschinger, M. (2010). Weak definites. Linguistic evidence for cognitive constraints. Talk presented at the Cognitive Science Research Training School, Universität Osnabrück.

Carlson, G. (1977). Reference to kinds in English. Ph. D. thesis, University of Massachusetts, Amherst.

Carlson, G. (2006). The meaningful bounds of incorporation. In S. Vogeleer \& L. Tasmowski (Eds.), Nondefiniteness and plurality (pp. 35-50). Amsterdam: John Benjamins Publishing Company.

Carlson, G., \& Sussman, R. S. (2005). Seemingly indefinite definites. In S. Kepser, \& M. Reis (Eds.), Linguistic evidence: Empirical, theoretical, and computational perspectives (pp. 71-86). Berlin/New York: Mouton de Gruyter.

Chierchia, G. (1998). Reference to kinds across language. Natural Language Semantics, 6(4), 339-405.

Chung, S., \& Ladusaw, W. A. (2004). Restriction and saturation. Cambridge, MA: MIT Press.

Dalrymple, M., Kanazawa, M., Mchombo, S., Peters, S. (1994). What do reciprocals mean? Semantics and Linguistic Theory (SALT), 4, 61-78.

Dayal, V. (1992). The Singular-plural distinction in Hindi generics. Semantics and Linguistic Theory (SALT), 2, 39-58.

Dayal, V. (2003). Bare nominals: Non-specific and contrastive readings under scrambling. In S. Karimi (Ed.), Word order and scrambling (pp. 67-90). Oxford: Blackwell Publishers.

Dayal, V. (2004). Number marking and indefiniteness in kind terms. Linguistics and Philosophy, 27, 393450 .

Dayal, V. (2011). Hindi pseudo-incorporation. Natural Language \& Linguistic Theory, 29(1), 123-167.

Dayal, V. (2013). On the existential force of bare plurals across languages. In I. Caponigro \& C. Cecchetto (Eds.), From grammar to meaning: The spontaneous logicality of language (pp. 49-80). Cambridge: Cambridge University Press.

Dayal, V. (2015). Incorporation: Morpho-syntactic vs. semantic considerations. In O. Borik, \& B. Gehrke (Eds.), The syntax and semantics of pseudo-incorporation (pp. 47-78). Leiden: Brill.

de Swart, H. D., Winter, Y., \& Zwarts, J. (2007). Bare nominals and reference to capacities. Natural Language \& Linguistic Theory, 25, 195-222.

Enç, M. (1991). The semantics of specificity. Linguistic Inquiry, 22(1), 1-25.

Espinal, M. T., \& McNally, L. (2011). Bare nominals and incorporating verbs in Spanish and Catalan. Journal of Linguistics, 47(1), 87-128.

de Farkas, D., \& Swart, H. (2003). The semantics of incorporation: From argument structure to discourse transparency. Stanford: CSLI Publications.

Farkas, D., \& de Swart, H. (2010). The semantics and pragmatics of plurals. Semantics \& Pragmatics, 3(6), $1-54$.

Francez, I. (2007). Existential propositions. Ph.D. thesis, Stanford University. 
Göksel, A. (2003). Syntactic head or morphological buffer? The auxiliary verb in Turkish. In A.S. Özsoy, E. Taylan, A. Koç, D. Akar, \& M. Nakipoğlu-Demiralp (Eds.), Studies in Turkish linguistics (pp. 49-57). Istanbul: Boğaziçi University.

Göksel, A., \& Kerslake, C. (2005). Turkish: A comprehensive grammar. London: Routledge.

Görgülü, E. (2012). Semantics of nouns and the specification of number in Turkish. Ph.D. thesis, Simon Fraser University.

Gračanin-Yüksek, M., \& İşsever, S. (2011). Movement of bare objects in Turkish. Dilbilim Araştırmaları, 22(1), 33-49.

Grice, H. P. (1975). Logic and conversation. In P. Cole \& J. L. Morgan (Eds.), Syntax and semantics: Vol. 3: Speech acts (pp. 41-58). New York: Academic Press.

Grimm, S. (2013). Plurality is distinct from number-neutrality. In Y. Fainleib, N. LaCara, \& Y. Park (Eds.), Proceedings of the 41st meeting of the North East Linguistic Society (NELS 41) (pp. 247-258). Amherst: GLSA.

Heim, I. (1991). Artikel und Definitheit. In A. von Stechow \& D. Wunderlich (Eds.), Semantics: An international handbook of contemporary research (pp. 487-535). Berlin: de Gruyter.

von Heusinger, K., \& Kornfilt, J. (2005). The case of the direct object in Turkish: Semantics, syntax and morphology. Turkic Languages, 9, 3-44.

Heyer, G. (1985). Generic descriptions, default reasoning, and typicality. Theoretical Linguistics, 11, 33-72.

Ionin, T., \& Matushansky, O. (2006). The composition of complex cardinals. Journal of Semantics, 23(4), 315-360.

Jespersen, O. (1927). A Modern English Grammar. Heidelberg: Carl Winter's Universitatsbuchhandlung.

Jo, J., \& Palaz, B. (2019a). Licensing pseudo-incorporation in Turkish. In M. Baird, \& J. Pesetsky (Eds.), Proceedings of the 49th meeting of the North East Linguistic Society (NELS 49) (pp. 155-164). Amherst: GLSA.

Jo, J., \& Palaz, B. (2019b). Non-canonical pseudo-incorporation in Turkish. Ms., University of Delaware.

Johanson, L. (1977). Bestimmtheit und Mitteilungsperspektive im türkischen Satz. Zeitschrift der Deutschen Morgenländischen Gesellschaft, Suppl., 3(2), 1186-1203.

Kamali, B. (2015). Caseless direct objects in Turkish revisited. ZAS Papers in Linguistics, 58, 107-123.

Kan, S. (2010). Number marking, blocking effects, and Turkish noun phrase. Ms., University of Massachusetts, Amherst.

Keenan, E. (1987). A semantic definition of indefinite NP. In E. Reuland \& A. ter Meulen (Eds.), The representation of (in)definiteness (pp. 286-317). Cambridge, MA: The MIT Press.

Kelepir, M. (2001). Topics in Turkish syntax: Clausal structure and scope. Ph. D. thesis, Massachusetts Institute of Technology.

Kelepir, M. (2003). Olmak, değil, var ve yok. In Proceedings of the XVIth Dilbilim Kurultayı (National linguistics conference) (pp. 70-81). Ankara: Hacettepe University.

Ketrez, N. (2004). -lAr-marked nominals and three types of plurality in Turkish. Proceedings from the Annual Meeting of the Chicago Linguistic Society (CLS), 39(1), 176-192.

Kleiber, G. (1990). L'article le generique: La genericité sur la mode massif. Geneva: Librairie Droz.

Kornfilt, J. (1984). Case marking, agreement, and empty categories in Turkish. Ph.D. thesis, Harvard University.

Kornfilt, J. (1996). On some copular clitics in Turkish. In A. Alexiadou, N. Fuhrhop, P. Law, \& S. Loehken (Eds.), ZAS papers in Linguistics (Vol. 6, pp. 96-114). Berlin: Zentrum für Allgemeine Sprachwissenschaft.

Kornfilt, J. (1997). Turkish. London: Routledge.

Kornfilt, J. (2009). DOM and two types of DSM in Turkish. In H. de Hoop \& P. de Swart (Eds.), Differential subject marking (pp. 79-111). Dordrecht: Springer.

Krifka, M. (2003). Bare NPs: Kind-referring, indefinites, both, or neither? Semantics and Linguistic Theory (SALT), 13, 180-203.

Krifka, M., \& Modarresi, F. (2016). Number neutrality and anaphoric update of pseudoincorporated nominals in Persian (and weak definites in English). Semantics and Linguistic Theory (SALT), 26, 847-891.

Krifka, M., Pelletier, F., Carlson, G., ter Meulen, A., Chierchia, G., \& Link, G. (1995). Genericity: An introduction. In G. Carlson \& F. J. Pelletier (Eds.), The generic book (pp. 1-124). Chicago: The University of Chicago Press.

Landman, F. (1989). Groups, I. Linguistics and Philosophy, 12(5), 559-605.

Landman, F. (2004). Indefiniteness and the type of sets. Oxford: Blackwell. 
Langford, C. H. (1949). The institutional use of 'the'. Philosophy and Phenomenological Research, 10, $115-120$.

Link, G. (1983). The logical analysis of plurals and mass terms: A lattice-theoretic approach. Reprinted in P. Portner \& B. H. Partee (Eds.), Formal semantics-The essential readings (pp. 127-147). New York: Blackwell, 2002.

Link, G. (1987). Generalized quantifiers and plurals. In P. Gärdenfors (Ed.), Generalized quantifiers (pp. 151-180). Dordrecht: Springer.

Martí, L. (2020a). Inclusive plurals and the theory of number. Linguistic Inquiry, 51(1), 37-74.

Martí, L. (2020b). Numerals and the theory of number. Semantics \& Pragmatics,13(3). https://doi.org/10. 3765/sp.13.3.

Massam, D. (2001). Pseudo noun incorporation in Niuean. Natural Language \& Linguistic Theory, 19(1), 153-197.

McNally, L. (1992). An interpretation for the English existential construction. Ph.D. thesis, University of California, Santa Cruz.

Milsark, G. (1974). Existential sentences in English. Ph.D. thesis, Massachusetts Institute of Technology.

Mithun, M. (1984). The evolution of noun incorporation. Language, 60(4), 847-894.

Öztürk, B. (2005). Case, referentiality, and phrase structure. Amsterdam: John Benjamins Publishing Company.

Öztürk, B. (2009). Incorporating agents. Lingua, 119, 334-358.

Öztürk, B., \& Taylan, E. E. (2016). Possessive constructions in Turkish. Lingua, 182, 88-108.

Renans, A., Sağ, Y., Ketrez, F. N., Tieu, L., Tsoulas, G., Folli, R., et al. (2020). Plurality and cross-linguistic variation: An experimental investigation of the Turkish plural. Natural Language Semantics, 28, 307342.

Sadock, J. (1980). Noun incorporation in Greenlandic: A case of syntactic word formation. Language, 56, 300-319.

Sauerland, U., Anderssen, J., \& Yatsushiro, K. (2005). The plural is semantically unmarked. In S. Kepser \& M. Reis (Eds.), Linguistic evidence: Empirical, theoretical and computational perspectives (pp. 413-434). Berlin/New York: Mouton de Gruyter.

Sağ, Y. (2018). The semantics of Turkish numeral constructions. Proceedings of Sinn und Bedeutung, 22(2), 307-324. https://ojs.ub.uni-konstanz.de/sub/index.php/sub/article/view/108/51.

Sağ, Y. (2019). The semantics of number marking: Reference to kinds, counting, and optional classifiers. Ph.D. thesis, Rutgers University.

Schwarz, F. (2014). How weak and how definite are weak definites? In A. Aguilar-Guevara, B.L. Bruyn, \& J. Zwarts (Eds.), Weak referentiality (pp. 213-135). Amsterdam: John Benjamins Publishing Company.

Schwarzschild, R. (1996). Pluralities. Dordrecht: Springer.

Scontras, G. (2014). The semantics of measurement. Ph.D. thesis, Harvard University.

Seidel, E. (2020a). Anaphoric potential of pseudo-incorporated nouns in Turkish. In H. Sofu, C. Can, A. D. Abik, M. Ö. Yüceol, \& A. Kilimci (Eds.), Turkish linguistics across boundaries: The Adana meeting (ICTL 18) (pp. 259-266). Wiesbaden: Harrassowitz.

Seidel, E. (2020b). Bare direct objects in Turkish: Pseudo-incorporated or weak arguments. In T. Bondarenko, C. Davis, J. Colley, \& D. Privoznov (Eds.), Proceedings of the 14th workshop on Altaic formal linguistics (WAFL 14) (pp. 277-287). Cambridge, MA: MITWPL.

Sezer, A. (1996). Türkçe’de Sözdizimsel Kısıtlamalar. In IX. Dilbilim Kurultayı Bildirileri (pp. 236-263). Bolu: Abant İzzet Baysal University.

Spector, B. (2007). Aspects of the pragmatics of plural morphology: on higher-order implicatures. In U. Sauerland \& P. Stateva (Eds.), Presupposition and implicature in compositional semantics (pp. 243281). London: Palgrave Macmillan.

Taylan, E. (1984). The function of word order in Turkish grammar. Berkeley, CA: University of California Press.

Tieu, L., \& Romoli, J. (2018). Plurality. (Eds.), The Oxford handbook of experimental semantics and pragmatics (pp. 208-227). Oxford: Oxford University Press.

van Geenhoven, V. (1998). Semantic incorporation and indefinite descriptions: Semantic and syntactic aspects of noun incorporation in West Greenlandic. Stanford: CSLI Publications.

Zucchi, S., \& White, M. (2001). Twigs, sequences and the temporal constitution of predicates. Linguistics and Philosophy, 24(2), 223-270.

Zweig, E. (2009). Number-neutral bare plurals and the multiplicity implicature. Linguistics and Philosophy, 32(4), 353-407. 
Publisher's Note Springer Nature remains neutral with regard to jurisdictional claims in published maps and institutional affiliations. 